Dzieje Najnowsze, Rocznik LIII - 2021, 3

PL ISSN 0419-8824

Adam Bosiacki

https://orcid.org/0000-0001-6455-0632

Wydział Prawa i Administracji Uniwersytetu Warszawskiego

\title{
Iwan Kriwoziercew jako świadek niektórych okoliczności zbrodni katyńskiej
}

\begin{abstract}
Abstrakt: Artykuł systematyzuje częściowo nieznane dotychczas aspekty biografii rosyjskiego chłopa Iwana Kriwoziercewa, będącego po 1945 r. do ujawnienia zbrodni w latach dziewięćdziesiątych XX w. najważniejszym świadkiem zbrodni katyńskiej. Tekst przedstawia szczegóły represji i śmierci ojca świadka, dostępne obecnie informacje na temat jego rodziny, ucieczki z miejsca zamieszkania, kompletu zeznań składanych polskim władzom i pisarzom oraz śledztwa podjętego po niewyjaśnionej do dziś śmierci Kriwoziercewa. Przedmiotem artykułu jest także prawnicza analiza i weryfikacja zeznań złożonych przez Kriwoziercewa, ocena pobudek postępowania świadka i rekonstrukcja charakteru postaci, także w związku z filmem fabularnym.
\end{abstract}

Słowa kluczowe: Iwan Grigorijewicz Kriwoziercew, zbrodnia katyńska, NKWD, 2 Korpus Polski, dipisi, Józef Mackiewicz, Ferdynand Goetel.

Abstract: The article systematises the previously unknown aspects of the biography of the Russian peasant Ivan Krivozertsev (1915-1947), who was the most important witness of the Katyn massacre after 1945 until the disclosure of this crime in the 1990s. The article presents details of the repression and death of the witness's father, currently available information about his family, escape from his place of residence, complete testimony to the Polish authorities and writers, and the investigation undertaken after the unexplained death of Ivan Krivozertsev. The article's subject is also the legal analysis and verification of testimonies made by Ivan Krivozertsev, the assessment of the witness' motives and the reconstruction of the witness's character in connection with the recently made feature film.

Key w ords: Ivan Grigorevich Krivozertsev, Katyn massacre, NKVD, 2nd Polish Corps, DPs (displaced persons), Józef Mackiewicz, Ferdynand Goetel. 
Do czasu oficjalnego przyznania się przez ZSRS do popełnienia tzw. zbrodni katyńskiej Iwan Grigorijewicz Kriwoziercew (1915-1947) ${ }^{1}$ był uznawany za najważniejszego świadka. Twierdziło tak kilku badaczy zajmujących się zagadnieniami zbrodni katyńskiej, a wynikało to przede wszystkim z faktu, że Kriwoziercewa uważano za jedynego, który zdołał znaleźć się na Zachodzie, a na pewno jedynego, który złożył zeznania. Sam to przyznawał, słusznie sądząc, że jako jedyny ma na ten temat najdokładniejsze informacje.

Jest to zarazem jedyny świadek ujawnienia fragmentu zbrodni katyńskiej, który przedostał się na Zachód po zakończeniu wojny i złożył swoje zeznania polskim organom i władzom wojskowym na uchodźstwie, a także dwóm pisarzom, pomimo że innych uciekinierów o podobnej wiedzy z okolic jego zamieszkania znalazłoby się jeszcze kilku.

Trzeba jednak poczynić zastrzeżenie, że wbrew niektórym publikacjom, także tłumaczonym na języki obce, Iwan Kriwoziercew nie był naocznym świadkiem zbrodni. Unikalność jego świadectwa polega na olbrzymiej wartości źródła pośredniego, świadka, który widział okoliczności zmierzające do jej popełniania, choć samej zbrodni oczywiście nie. Kriwoziercew należy zatem do grupy osób, które zetknęły się ze zbrodnią katyńską czy ściślej z jej ujawnieniem, ale także do nielicznej grupy osób obserwujących niektóre przygotowania do popełnienia zbrodni. W przyszłości prawie wszyscy świadkowie niepełnych okoliczności zbrodni (z wyjątkiem jednak delegacji zagranicznych, przywożonych przez Niemców na teren ekshumacji, ale tylko z krajów niepozostajacych po wojnie pod wpływami ZSRR) podlegali z tego tytułu represjom ze strony władz sowieckich, także poza granicami ZSRR ${ }^{2}$.

${ }^{1} \mathrm{~W}$ piśmiennictwie polskim jako transkrybowany z języka rosyjskiego do niedawna stosowano zapis nazwiska „Kriwoziercow”. Wydaje się to jednak błędne wobec braku litery „ë” w końcówce nazwiska. Na częste przekręcanie nazwiska „Kriwoziercew” na „Kriwoziercow” zwróciła współcześnie uwagę Anna Zachenter. A. Zachenter, Oni wciqż sq i robia swoje, „Dziennik Polski”, 14 IX 2009, https://dziennikpolski24.pl/oni-wciaz-sa-i-robia-swoje/ ar/2646822 (dostęp: 17 VII 2020).

${ }^{2}$ Por. w szczególności: T. Wolsza, Katyń 1940. Świadkowie i świadectwa (PDF udostępniony dzięki uprzejmości Autora); idem, Jak Sowieci mścili się na lekarzach katyńskich, https:// nowahistoria.interia.pl (dostęp: 6 III 2020); idem, „To co widziatem przekracza swa groza najśmielsze fantazje". Wojenne i powojenne losy Polaków wizytujacych Katyń w 1943 roku, Warszawa 2015; Niemiecki urzędowy materiat $w$ sprawie masowego mordu $w$ Katyniu, red. nauk. A. Bosiacki, tłum. P. Bentkowski, Warszawa 2020, s. 24-27. W ostatniej ze wskazanych publikacji (s. 15) stwierdziłem, że naocznymi świadkami nie byli członkowie delegacji zagranicznych, wizytujący ekshumacje w lesie katyńskim, ani miejscowi mieszkańcy. Dopiero w prowadzonym u schyłku istnienia ZSRS dochodzeniu (1989-1990) po raz pierwszy uznano, że „w różnych regionach kraju odnaleziono naocznych świadków, którzy złożyli zeznania [dotyczące] tragicznego losu polskich oficerów”. Informacja Prokuratora Generalnego ZSRR N. Trubina dla prezydenta M. Gorbaczowa, 17 maja 1991, w: Katyń. Dokumenty ludobójstwa. Dokumenty i materiaty archiwalne, przekazane Polsce 14 października 1992 r., tłum. W. Materski, Warszawa 1992, s. 141. Do dziś jednak zeznania takich świadków pozostają tajne, z nielicznymi wyjątkami, jak zeznania prawdopodobnie 
Celami artykułu są w szczególności weryfikacja zeznań złożonych przez Iwana Kriwoziercewa, ocena pobudek postępowania świadka i rekonstrukcja charakteru postaci, także w związku z filmem fabularnym zrealizowanym ostatnio na temat jego śmierci ${ }^{3}$. Paradoksalnie materiałów na temat postaci Kriwoziercewa nie ma zbyt wiele, a dostępne powielają ustalenia sprzed wielu lat. Materiały archiwalne przeanalizowane na potrzeby niniejszego artykułu pozwoliły także na skorygowanie kilku innych twierdzeń związanych z osobą świadka.

Badaczom zbrodni katyńskiej biografia Iwana Kriwoziercewa jest dokładnie znana. W piśmiennictwie polskim spopularyzował ją Józef Mackiewicz, najpierw w opublikowanej w 1948 r. książce w języku niemieckim, wkrótce wydanej po angielsku ${ }^{4}$, a później w nieco skróconej wersji w fundamentalnej przez dziesięciolecia pracy Zbrodnia katyńska w świetle dokumentów ${ }^{5}$, której do końca jej wydań pozostał anonimowym redaktorem. W związku ze śmiercią Kriwoziercewa Mackiewicz opublikował także artykuł w londyńskich „Wiadomościach”. Biografia Kriwoziercewa opiera się zatem na jego własnym świadectwie w formie biografii, zestawionej na tej podstawie w dwóch książkach i dwóch artykułach przez Mackiewicza ${ }^{6}$, i w niemal identycznej biografii zamieszczonej przez Ferdynanda Goetla, który opracował ja na polecenie władz polskich w Ankonie w 1946 r. $^{7}$ (być może zreszta tak jak Mackiewicz). Analogicznie także Goetel opublikował po śmierci Kriwoziercewa artykuł w „Wiadomościach”. Obie spisane biografie różnią się minimalnie, świadcząc jednak, że najprawdopodobniej pierwotną jest opublikowana później, w 1955 r., bardziej miejscami wyczulona na szczegóły relacja Goetla8.

bezpośredniego oprawcy Mitrofana Syromiatnikowa (1908-1995) i kierujacych, odpowiednio, Zarządem Jeńców Wojennych NKWD ZSRS Piotra Soprunienki (1908-1992) oraz Zarządem NKWD w Kalininie Dmitrija Tokariewa (1902-1993), według którego jeden z zastępców Berii, Bogdan Kobułow (1904-1953), wyraźnie wskazał, że oprócz wykonawców zbrodni nie może być ani jednego żywego świadka. Por. np.: Katyń. Dokumenty zbrodni, t. II: Zagtada, marzec-czerwiec 1940, red. W. Materski i in., Warszawa 1998, s. 442; N. Pietrow, Poczet katów katyńskich, tłum. J. Prus-Wojciechowska, Warszawa 2015, s. 46-48.

${ }^{3}$ Katyń - Ostatni świadek (The Last Witness), polsko-brytyjski film sensacyjny z 2018 r.; reżyseria Piotr Szkopiak.

4 J. Mackiewicz, The Katyn Wood Murders, wyd. 1, London 1951, wyd. pol. 1: idem, Katyń. Zbrodnia bez sqdu i kary, zebrał i oprac. J. Trznadel, t. I, Warszawa 1997, s. 6-232.

${ }_{5}$ Zbrodnia katyńska $w$ świetle dokumentów, przedmowa W. Anders, wyd. 1, Londyn 1948 (wyd. 13, Londyn 1989). Następne wydania książki nie ukazywały się z powodu dezaktualizacji wielu zawartych w niej hipotez. Każde wydanie było aktualizowane po weryfikacji pojawiajacych się materiałów.

${ }_{6}$ Zob. przypis 3 prezentowanego artykułu.

7 F. Goetel, Czasy wojny, wyd. 1, Londyn 1955, s. 259-274 (wyd. 2, Gdańsk 2000).

${ }^{8} \mathrm{~W}$ cytowanych $\mathrm{w}$ dalszej części artykułu materiałach archiwalnych nie występuje jakikolwiek ślad rozmowy Mackiewicza z Kriwoziercewem. Pisarz jest natomiast autorem artykułu o niewyjaśnionej do dziś śmierci Rosjanina, powstałego na podstawie śledztwa przeprowadzonego przez polskie władze wojskowe (patrz dalej). 
Inne opracowania naukowe i popularne $\mathrm{w}$ piśmiennictwie polskim, a $\mathrm{w}$ ślad za nimi także w obcych ${ }^{9}$, opieraja się na tych właśnie pracach, przeinaczając czasem bądź też dodając szczegóły wypaczające charakter i znaczenie postaci Kriwoziercewa ${ }^{10}$, czyniąc to nawet $\mathrm{w}$ dobrej wierze. Przeinaczanie takie miało miejsce nie tylko w przeszłości, gdy szczupłość źródeł ograniczała mocno możliwość badań, lecz występuje często obecnie.

Na podstawie wskazanych źródeł wiadomo, że Iwan Kriwoziercew urodził się 20 VII 1915 r. we wsi Nowyje Batioki (ros. Новые Батёки) ${ }^{11}$ w rodzinie chłopskiej. Jak na współczesne rosyjskie warunki rodzina nie była wielodzietna: Kriwoziercew miał tylko dwie siostry (starszą i młodsza). Miejscowość oddalona jest dokładnie $2 \mathrm{~km}$ od stacji kolejowej Gniozdowo (ros. Гнёздово, pochodzacej od ros. wyrazu „gniazdo”, w spolszczonej popularnej wersji tłumaczona jako „Gniezdowo”) ${ }^{12}$, do której, jak wiadomo, przywożono część transportów

${ }_{9}^{9}$ Zob. np.: C. Weber, Krieg der Täter. Die Massenerschießungen von Katyń, Hamburg 2015, s. 159-173 czy książkę Thomasa Urbana, Katyń. Zbrodnia i walka propagandowa wielkich mocarstw, tłum. E. Ziegler-Brodnicka, Warszawa 2019.

10 Zob. np.: A. Zachenter, op. cit. Autorka myli dwie prace Mackiewicza i podaje błędną liczbę areału ziemi należącej do rodziny Kriwoziercewów. Zauważa natomiast częste przekręcanie nazwiska Kriwoziercewa na Kriwoziercow. Spośród wydanych ostatnio prac o Katyniu szczególnie dużą liczbę błędów w odniesieniu do osoby Kriwoziercewa popełnili Eugenia Maresch w książce Katyń 1940 (tłum. z ang. M. Urbański, Warszawa 2014) oraz Thomas Urban (op. cit.). W odniesieniu do Kriwoziercewa autorka używa określenia „świadek mordu” (E. Maresch, op. cit., s. 9), zaliczając go do „świadków naocznych” (ibidem, s. 81, 84), podając błędną informację, że był „białoruskim chłopem” (ibidem, s. 78), „mieszkał w bezpośrednim sassiedztwie i widział, co działo się w Lesie Katyńskim” (ibidem, s. 79). Abstrahując nawet od nieznajomości terminów określających świadków czy też niezauważenia narodowości Kriwoziercewa, umieszczonej w nagłówku zeznań w książce Zbrodnia katyńska $w$ świetle dokumentów, podobna nonszalancję na temat tej postaci autorka prezentuje w innych miejscach narracji, np.: „Wobec postępów ofensywy sowieckiej we wrześniu 1943 roku [Kriwoziercew] opuścił te tereny wraz z wycofującymi się wojskami niemieckimi; pracował później na kolei w Berlinie [...]. Do Wielkiej Brytanii Kriwoziercow przybył wraz z 2 Korpusem, przybrał nowe nazwisko (Michał Łoboda) i stał się nałogowym alkoholikiem" (E. Maresch, op. cit., s. 79). Na pytanie, skierowane do autorki, skąd dysponuje wiedza, że Kriwoziercew został alkoholikiem, usłyszałem, że „skoro pili codziennie, to stał się alkoholikiem” (rozmowa z E. Maresch, Londyn, 27 VI 2019 r.). Wskazanych twierdzeń autorka w żaden sposób nie uzasadnia (w przytoczonych stwierdzeniach brak też zawsze przypisów uzasadniajacych podobne pseudohipotezy). W odróżnieniu od wielu innych cytowana książka zawiera jednak zeznania Kriwoziercewa (choć literalnie powtarzane i z niezweryfikowanymi nazwami, jak Gniezdowa zamiast Gniezdowo, s. 101). Praca Urbana także zawiera wiele nieścisłości na temat Kriwoziercewa, z których do kilku odniosę się w tekście (autor pisze np., że pewnej nocy Kriwoziercewa odwiedzili sowieccy partyzanci, z którymi nieufny nie chciał iść; Th. Urban, op. cit., s. 422-423). Podobne publikacje, jak jest to przyjęte nie tylko w Polsce, przed wydaniem warto opatrzeć recenzją wydawnicza, co w obu przypadkach niestety nie nastapiło.

11 Niemiecki urzędowy materiat..., s. 46.

${ }^{12}$ Po raz pierwszy nazwę tę zawarłem w opracowaniu książki Niemiecki urzędowy materiat... 
przeznaczonych na egzekucję w części lasu katyńskiego, zwanej Kozie Góry, bądź rzadziej Kosogory, niespełna $8 \mathrm{~km}$ od miejsca kaźni, nieco ponad $4 \mathrm{~km}$ od obecnego położenia Polskiego Cmentarza Wojennego w Katyniu i nieco ponad $11 \mathrm{~km}$ od miejscowości o tej właśnie nazwie (Katyń, ros. Катынь). Miejsce zbrodni znajduje się zatem mniej więcej w połowie drogi między wsiami Nowyje Batioki i Katyń, gdy zwyczajowo nazwę zbrodni kojarzy się tylko z tą ostatnia miejscowościa. Topografia miejsca jest istotna nie tylko z powodu nazw miejscowości i często ich błędnej transkrypcji w języku polskim, ale té̇ z uwagi na fakt, że w śledztwie niemieckim z 1943 r. żaden ze świadków niektórych okoliczności zbrodni nie pochodził z Katynia, gdzie nocowali m.in. przez wiele dni członkowie ekspedycji Polskiego Czerwonego Krzyża (PCK; np. Marian Wodziński).

Według relacji Kriwoziercewa po przejęciu władzy przez bolszewików nie nastapiły istotne zmiany w położeniu rodziny. Z powodu dziecięcego wieku i prawdopodobnych obaw o rozgłaszanie informacje takie posiadał jednak z opowiadań bliskich. W $1926 \mathrm{r}$. rodzinie odebrano ponad połowę areału (6 ha) z 10 dziesięcin ziemi (ok. 11 ha ${ }^{13}$, czego jednak nie uznano za tragedię. Prawdziwe nieszczęście sprowadziła 3 lata później kolektywizacja, gdy ojca Iwana Kriwoziercewa zaliczono do grupy bogatych chłopów (tzw. kułaków), co skutkowało, jak podał syn, zawsze szybkim uwięzieniem. Według wersji syna ojciec uciekł więc wraz z matką Jewdokią i młodszą siostra na Ural, a Iwan ze starszą o 2 lata siostrą Daria, której imię poznaliśmy z jego zeznań przed Niemcami, co podobnie jak imię matki można potwierdzić w bazach danych list ofiar stalinowskich represji dopiero współcześnie (w odróżnieniu od nieznanych imion pozostałych członków rodziny) ${ }^{14}$, pozostał na miejscu, podejmujac pracę w utworzonym wtedy, bądź wcześniej, kołchozie, do którego ojciec nie należał. Typowe wtedy dla milionów zachowanie mądrego ojca rodziny ${ }^{15}$ zostało zakłócone jego powrotem po dwóch latach, spowodowanym, zdaniem syna, tęsknota ${ }^{16}$, jak można domniemywać - oczywiście bardziej za pozostawionymi dziećmi niż za rodzinnymi stronami, choć jak podaje Goetel, powracający sądził, że już o nim jako tzw. kułaku zapomniano ${ }^{17}$. Prawie na pewno jednak ojciec Iwana Kriwoziercewa został wtedy skazany na zesłanie wraz z żoną i jedna z córek. Świadczą o tym ujawnione obecnie personalia represjonowanych ${ }^{18}$. Co także charakterystyczne, ojciec pozostał wtedy

${ }^{13}$ F. Goetel, Czasy wojny..., s. 260; J. Mackiewicz, Katyń..., s. 139.

${ }_{14}$ Matka Iwana, Jewdokija Denisowna Kriwoziercewa (1879-?) została represjonowana w 1930 r. na niewiadomą karę (prawdopodobnie zesłania na Ural, o czym wspominał syn). Zob. https://base.memo.ru/person/show/2142864 (dostęp: 17 VII 2020).

${ }_{15}$ O. Figes, Szepty. Życie w stalinowskiej Rosji, tłum. W. Jeżewski, Warszawa 2008.

16 J. Mackiewicz, Katyń..., s. 140.

${ }^{17}$ F. Goetel, Czasy wojny..., s. 260.

${ }_{18}$ Dane Grigorija Siemionowicza Kriwoziercewa za: https://base.memo.ru/person/show/2142864 (dostęp: 17 VII 2020). 
z dziećmi, a dopiero „nie za długo został aresztowany i osadzony w więzieniu”" Według przytaczanej relacji syna powodem była sankcja z art. 58-10 Kodeksu karnego RFSRR z 1926 r., co oznaczało prawdopodobnie tzw. kontrrewolucyjna agitację i propagandę, za którą uchodziło choćby wypowiedzenie krytycznej uwagi o fragmencie otaczającej rzeczywistości. Iwan Kriwoziercew nie znał dokładnego powodu aresztowania ojca. Jak słusznie stwierdził, „u nas zna się zazwyczaj tylko numer paragrafu, a nie jego treść" ${ }^{20}$. Dodał jednak, że dając niekiedy wyraz w rozmowach swym niezmiennym zapatrywaniom, ojciec został aresztowany na podstawie donosu jednego z krewnych ${ }^{21}$. Skazany według wiedzy syna na 10 lat obozu pracy, następnie zwolniony jako niezdolny do pracy po dziewięciu miesiącach, wrócił „do rodzinnej wsi, w której był ongiś gospodarzem, a dziś parobkiem pańszczyźnianym kołchozu”22. Według relacji przytoczonej przez Goetla nie został przyjęty do kołchozu, pracując jako szklarz. Podług relacji spisanej przez Mackiewicza - „zaszczuty politycznie, zostaje wykluczony z kołchozu" ${ }^{23}$. Aresztowany powtórnie w 1934 r., został rozstrzelany w czasie wielkiej czystki trzy lata później, o czym syna Iwana poinformowano pośrednio $\mathrm{w}$ wyniku zapytania skierowanego przez rodzinę do władz (prawdopodobnie NKWD) ${ }^{24}$. Stosowne pismo stwierdza, że miejsce pobytu ojca jest nieznane. „To u nas tak zawsze”, konkludował Iwan Kriwoziercew, „gdy kogoś rozstrzelają bez sądu...”25

Opierając się na obecnej wiedzy, należy uznać, że twierdzenia i przypuszczenia syna odnośnie do losu ojca odpowiadaja prawdzie. Grigorij Siemionowicz Kriwoziercew (1878-1937) po raz pierwszy został represjonowany w 1930 r. wraz ze swą żoną i córką Darią (ur. 1913). Represja polegała prawdopodobnie na zesłaniu na Ural, o czym syna jako dziecka zapewne nie poinformowano. Po raz drugi Grigorij Kriwoziercew został skazany na 10 lat obozu pracy poprawczej (czyli łagru) decyzją pełnomocnej trójki, tzw. Kolegium Specjalnego OGPU ZSRR, smoleńskiego OGPU, 29 XII $1932 \mathrm{r.}^{26}$ Aresztowano go wcześniej, 31 października tego samego roku. Zgadza się również podana $\mathrm{w}$ tym wypadku przez syna podstawa prawna represji: art. 58-10 kk RFSRR z 1926 r. ${ }^{27}$ Po raz trzeci Grigorij Kriwoziercew został

\footnotetext{
19 J. Mackiewicz, Katyń...

${ }^{20}$ Ibidem.

${ }^{21}$ F. Goetel, Czasy wojny...

22 J. Mackiewicz, Katyń...

${ }^{23}$ Ibidem. W tym miejscu więcej szczegółów losu ojca Iwana Kriwoziercewa podał Mackiewicz: „Jeszcze rok, dwa, błąkał się ojciec po okolicy, aż w roku 1934 zostaje ponownie aresztowany. Tym razem nikt nie zna nawet paragrafu i zresztą nikt się tym nie interesuje”. Ibidem.

${ }^{24}$ F. Goetel, Czasy wojny..., s. 260; J. Mackiewicz, Katyń...

${ }_{25}$ J. Mackiewicz, Katyń...

${ }^{26}$ Baza Stowarzyszenia Memoriał, Moskwa, Żertwy politiczeskogo terrora w SSSR, Spiski żertw, https://base.memo.ru/person/show/2123112 (dostęp: 1 VIII 2020).

27 Ibidem.
} 
aresztowany przez funkcjonariuszy 5 Wydziału Zarządu Bezpieczeństwa Państwowego NKWD Obwodu Zachodniego (UGB NKWD Zapadnoj Obłasti) w Smoleńsku 20 VII 1937. Przy poprzednich aresztowaniach figurował jako robotnik i bezpartyjny. Przy ostatnim zatrzymaniu w rubryce zawód wpisano „szklarz” (stiekol'szczik), co było zgodne ze świadectwem syna. Podobnie rzecz miała się z zastosowaniem wymiaru kary. 5 IX 1937 wyrokiem trójki Zarządu NKWD Obwodu Smoleńskiego Grigorij Kriwoziercew został skazany na karę śmierci. Wyrok wykonano 14 IX 1937 r. ${ }^{28}$

Iwan Kriwoziercew był przekonany, że ojca pogrzebano w Kozich Górach, czyli części lasu katyńskiego, gdyż jak wiadomo, od dawna znajdowało się tam miejsce kaźni. Według dzisiejszej wiedzy okazało się, że miał rację. Jak stwierdza lokalna baza Stowarzyszenia Memoriał, ojciec Iwana został pogrzebany właśnie w lesie katyńskim, czyli miejscu tajnego pochówku także więźniów z Kozielska - Kozich Górach albo Kosogorach ${ }^{29}$. Grigorij Kriwoziercew został zrehabilitowany 11 XII 1958 r., a jego żona i córka - dopiero po upadku ZSRR, w 1996 r. ${ }^{30}$

Iwan Kriwoziercew ukończył siedmioklasową szkołę, a następnie został tokarzem w metalu. Był to na pewno atrakcyjny zawód, mogacy gwarantować odpowiednia pozycję na wsi czy też w kołchozie. Kriwoziercew miał jednak dużo szczęścia, że nie ucierpiał podczas represji. Był oczywiście niepewnym elementem społecznym, podejrzanym politycznie z racji represji przeprowadzonych wobec ojca. W czasie wielkiej czystki, w 1937 r., został więc powołany tylko formalnie do wojska, a dokładniej do tzw. batalionów pracy, jak przyznawał, „bez prawa noszenia broni. Stroitiel'nyje wojska”. Stroitiel'nyje bataliony (w sowieckim skrócie strojbat) grupowały tzw. osoby niezdolne do pracy (nietrudowyje elemienty), do których jednak, wbrew nazwie, zaliczano kułaków czy ich dzieci, byłe najczęściej duchowieństwo, byłych urzędników itd. Jak twierdził Kriwoziercew, został on także szybko zwolniony z tzw. batalionów pracy na skutek astygmatyzmu źrenic. Powrócił do wsi, pracujacc jako ślusarz, i wstapił do kołchozu w 1940 r. Jak pisał, po powrocie ze służby w tzw. batalionach pracy nie mógł już mieszkać we własnym domu, stosunki w kołchozie były jednak dobre, a mógł też liczyć na pomoc wielu ludzi w okolicy. Z powodu stwierdzonej wcześniej choroby nie został też zmobilizowany do walki w dwóch kolejnych wojnach: sowiecko-fińskiej i przeciw

${ }^{28}$ Baza Stowarzyszenia Memoriał, op. cit., https://base.memo.ru/person/show/2123113 (dostęp: 17 VII 2020) oraz Lista Rosjan, pogrzebanych w lesie katyńskim, których udało się zidentyfikować na podstawie danych archiwum FSB w Smoleńsku od ok. połowy lat dziewięćdziesiątych. Katyn Memorial, http://memorial-katyn.ru/ru/martirolog.html, poz. 1377 (dostęp: 29 VII 2020). Lista zawiera 2987 nazwisk, a Grigorij Siemionowicz Kriwoziercew znajduje się na niej pod pozycją 1377.

${ }^{29}$ Ibidem.

${ }^{30}$ Baza Stowarzyszenia Memoriał, Moskwa, op. cit. 
Niemcom. Miał jednak szczęście, że nie podlegał dalszym represjom ${ }^{31}$, choć powrót na wieś nie był typowy dla wielu ludzi jego pokroju. Musiał się bowiem wiązać z naturalnym brakiem perspektyw jakiegokolwiek awansu społecznego.

Dalsza biografia Kriwoziercewa, chociaż szeroko znana w literaturze zbrodni katyńskiej, przy bliższej analizie jest w wielu miejscach niejednoznaczna. Obserwujący transporty z Gniazdowa, oddalonego o kilometr drogi od wsi Głuszczenki (w literaturze błędnie: Gruszczenka, rzadziej Gruszczenki) ${ }^{32}$, gdzie teraz mieszkał, zauważył, jak wiadomo, transporty $\mathrm{z}-$ jak się potem okazało - umundurowanymi jeńcami obozu w Kozielsku, a czasami także z księżmi, jadące od stacji Gniozdowo w kierunku Kozich Gór, które powszechnie uchodziły za miejsce straceń. Kriwoziercew twierdził, że widział wiele takich transportów: pierwszy 14 kwietnia, następne zaś „przez cały kwiecień". Może to jednak kłócić się z wiedza, że większość egzekucji dokonywano w budynku Obwodowego Zarządu NKWD w centrum Smoleńska (ul. Dzierżyńskiego 13) ${ }^{33}$.

Motywy obserwacji transportów, poczynione przez Kriwoziercewa, nie były jasne dla niego samego. Jak pisał, był głęboko poruszony, podobnie jak inni, kierowała nim ciekawość, ale także pamięć o ojcu i jego krzywdzie, która przy tej okazji odżyła w nim z nową siła. Notował w pamięci każde zdarzenie $^{34}$, uważając oczywiście, by nie narazić się ,zbyteczną ciekawościa i gadatliwością. O wiadomości nie było zbyt trudno”, jak twierdził, „gdyż

${ }^{31}$ Po zakończeniu wielkiej czystki w listopadzie 1938 r. w ZSRR miała miejsce pewna liberalizacja. Z obozów pracy wypuszczono ok. 1,1 mln ludzi. Jak wiadomo jednak z wielu materiałów archiwalnych, do tego czasu zwracano uwage na nasilenie działalności „,antysowieckich elementów", w szczególności na wsi spośród osób zmobilizowanych do strojbatalionów, m.in. na Smoleńszczyźnie. Zob. np.: Specsobszczenije 9 otdieła 1 Uprawlienija NKWD SSSR N.I. Jeżowu o reakcii nasilenija smolenskoj obłasti na oczerednoj prizyw $w$ RKKA, 7 awgusta 1938, w: Tragedija sowietskoj dieriewni. Kollektiwizacija i raskułacziwanije. Dokumienty i materiaty, t. V: 1937-1939, kn. 2: 1938-1939, Moskwa 2006, s. 187.

32 Nazwę „Gruszczenka” podawał błędnie Mackiewicz w redagowanej, jak była mowa, anonimowo książce Zbrodnia katyńska w świetle dokumentów (wyd. 13, np. s. 262). Nazwę „Gruszczenki” przytoczył z kolei Goetel (Czasy wojny..., s. 261). Obu nazw nie podaje natomiast Niemiecki urzędowy materiat...

${ }^{33}$ Nawiasem mówiąc, świadectwo Kriwoziercewa na temat rodzajów samochodów w kolumnie, z samochodami do przewożenia więźniów (tzw. czarnymi krukami, ros. czornyj woron), kłóci się też ze znaną relacją prof. Stanisława Swianiewicza, twierdzącego, że w transporcie z 29 na 30 IV 1940 r. z Gniazdowa na miejsce kaźni po więźniów przyjeżdżał „zwykły pasażerski autobus” z oknami zasmarowanymi wapnem. S. Swianiewicz, W cieniu Katynia, Paryż 1989, s. 110. Mogła to jednak być nadzwyczajna sytuacja, pomimo że według wiarygodnych stwierdzeń Kriwoziercewa czornych woronow było w lesie katyńskim cztery, a każdy z nich przeznaczony najwyżej dla ośmiu więźniów. Jednym z takich samochodów Swianiewicz został odwieziony do wewnętrznego więzienia NKWD w Smoleńsku. Ibidem.

${ }^{34}$ Zob. F. Goetel, Czasy wojny..., s. 262-263; Zbrodnia katyńska w świetle dokumentów..., s. 203. 
ludność miejscowa, zdumiona i wzburzona wewnętrznie, dlaczego rozstrzeliwują Polaków, rozprawiała dużo [po cichu] o Kozich Górach"35.

Jak napisano w niepublikowanych materiałach dochodzenia prowadzonego przez organy polskiego wywiadu na uchodźstwie, badające śmierć świadka, „Kriwoziercew zameldował Niemcom o sprawie katyńskiej stosunkowo późno, bo w r. 1943 [...], a to dlatego, że nie przypuszczał on, że sprawa ta może ich interesować. Zgłosił się dopiero wówczas, gdy dowiedział się z miejscowych gazet i od Niemców o zaginięciu w Rosji większej liczby oficerów polskich i zorientował się, że Niemcy tą sprawą żywo się interesują"36.

Pierwsze zeznania na temat zbrodni katyńskiej Kriwoziercew złożył Niemcom w lutym 1943 r. Według współczesnych niemieckich badań mówi się także o krążących wśród mieszkańców plotkach na temat rozstrzelania Polaków w lesie Kozie Góry. Mgliście dysponowali takimi informacjami Niemcy już w sierpniu 1942 r., a w październiku 1941 r. dotarły do nich ponoć podobne wiadomości, gdy w daczy w Kozich Górach zamieszkał dowódca 537 Nachrichten-Regiments, prawdopodobnie płk Friedrich Ahrens (w raporcie sowieckim z 1944 r. uznany za głównego sprawcę egzekucji Polaków). Informacji o pogrzebaniu zwłok Polaków miał dostarczyć jako pierwszy niezidentyfikowany jeniec sowiecki. Najpóźniej w lutym 1942 r. zeznanie o egzekucjach złożył podobno miejscowy chłop, Parfion Kisielow ${ }^{37}$, jednak śladów na ten fakt nie odnaleziono. Mniej więcej po miesiącu, w marcu 1942 r., najwyraźniej po niepodjęciu sprawy przez Niemców, miejscowi chłopi o miejscu zbrodni zawiadomili ponoć polskich robotników z Organizacji Todt, stacjonujących przy robotach podkładów kolejowych w Gniazdowie. Przyszli oni noca do mieszkającego najbliżej miejsca kaźni Kisielowa, pożyczając narzędzia do rozkopania ziemi, a po natrafieniu na zwłoki postawili rodakom na nieoznaczonych mogiłach dwa drewniane krzyże. Fakt ten również pozostał bez echa ${ }^{38}$, choć bez problemu można było w takim stanie faktycznym zidentyfikować groby, jeśliby ktoś o fakcie rozgrzebania mogił poinformował Niemców. Nasuwa się przy tym nieodparte wrażenie, że z jakichś względów

${ }^{35}$ Zbrodnia katyńska $w$ świetle dokumentów..., s. 204. W relacji, zamieszczonej w książce Goetla (Czasy wojny..., s. 263), brak wyrażenia „po cichu”, dodanego przez Mackiewicza, a zamiast o Kozich Górach Kriwoziercew mówi o Katyniu („ludność miejscowa, zdumiona i wzburzona wewnętrznie, dlaczego rozstrzeliwują Polaków, rozprawiała dużo o Katyniu"), czego na pewno nie użył miejscowy mieszkaniec na określenie zbrodni, a co jest już skrótem myślowym zastosowanym przez polskiego pisarza.

${ }^{36}$ Archiwum Instytutu Polskiego i Muzeum im. gen. Sikorskiego w Londynie (dalej: AIPMS), Katyń, kol. 13/3, teczka „Kriwoziercow”, P. Jankowski, Uwagi do protokołu Iwana Kriwoziercewa, spisanego w Niemczech w dniu 31 maja 1945 roku, 21.11.1951 r., k. 37d. Jak wiele materiałów archiwalnych, umieszczonych w teczce, tekst zawiera również nieścisłości, podając np., że świadek urodził się w Gniezdowie. Ibidem.

${ }^{37}$ Ostatni akapit cyt. za: A. Bosiacki, Wstep, w: Niemiecki urzędowy materiat..., s. 21.

${ }^{38}$ Po raz pierwszy na ten temat pisał Mackiewicz w książce Katyń..., s. 154 i n.; ostatnio m.in. w: A. Bosiacki, op. cit. 
Niemcy nie byli zainteresowani otwarciem mogił, bowiem wyraźnie, choćby poprzez postawienie krzyży w miejscu postoju części jednostki wojskowej, zostali o fakcie poinformowani. Jednocześnie, według wersji samego zainteresowanego, w początkach lutego $1943 \mathrm{r}$. Kriwoziercew, po przeczytaniu informacji o zaginięciu polskich oficerów w wychodzącej dwa razy w tygodniu w Smoleńsku kolaboranckiej gazecie „Nowyj Put” („Nowa Droga”), poprzez tłumacza dowódcy miejscowej Tajnej Policji Polowej (Geheime Feldpolizei) poinformował Niemców o fakcie tajnego pogrzebania jeńców z Kozielska. Tłumacz tylko pozornie nie okazał zainteresowania wiadomością ${ }^{39}$ (prawdopodobnie z uwagi na możliwą samowolę miejscowej ludności przy rozkopywaniu grobów). 17 bądź 18 lutego z udziałem Kriwoziercewa rozpoczęto odkopywanie mogit ${ }^{40}$.

Kriwoziercew złożył władzom niemieckim co najmniej trzy zeznania. W niemieckim „Urzędowym materiale w sprawie masowego mordu w Katyniu" figuruja one niechronologicznie pod datami: 27 II, 5 IV i 18 IV 1943 r. Pierwsze zeznanie, zapisane pod datą 27 II 1943 r., dotyczy ogólnych aspektów okoliczności zbrodni z 1940 r., drugie doprecyzowuje wiedzę świadka na ten temat. Kriwoziercew mówi w nim zatem wszystko, co wie na temat części lasu katyńskiego, w którym dokonywano rozstrzeliwań, nie tylko w 1940 r., choć temu zagadnieniu poświęcona jest odrębnie ostatnia część zeznania. Ostatnie z zeznań Kriwoziercewa, zawarte w raporcie niemieckim z 1943 r., stanowi, z jednym wyjątkiem, zaprzysiężenie złożonych wcześniej zeznań przed Dowództwem Grupy Armii Środek Naczelnego Dowództwa Wehrmachtu.

W pierwszym zeznaniu, które złożył władzom niemieckim, dotyczącym tła zbrodni, Kriwoziercew stwierdził, że ponieważ miejsce pracy świadka znajdowało się bardzo blisko linii kolejowej, „w marcu i kwietniu 1940 r.”, zauważył on:

3-4 pociagi dziennie przychodzące ze Smoleńska, każdy z 3-4 wagonami, które po zakratowanych oknach bez problemu rozpoznałem jako więźniarki. Te więźniarki odstawiano na stacji w Gniezdowie. Moja siostra Daria opowiadała mi potem, że widziała, jak z tych wagonów ładowano do zamkniętych ciężarówek polskich żołnierzy, cywilów, a nawet kilku duchownych. Powszechnie słyszało się, że ciężarówki pojechały do Kozich Gór, do NKWD, i tam tych ludzi rozstrzelano. Osobiście tego nie widziałem, moja siostra też nie przekazała mi żadnych szczegółów ${ }^{41}$.

Niemiecki raport dodawał później, że siostra Kriwoziercewa, Daria została ewakuowana przez Rosjan w 1941 r., opiekując się bydłem w kołchozie i przebywa obecnie w niewiadomym miejscu.

\footnotetext{
${ }^{39}$ Zob. J. Trznadel, Rosyjscy świadkowie Katynia (1943-1946-1991), w: Zbrodnia katyńska. Droga do prawdy, red. M. Tarczyński, Warszawa 1992 („Zeszyty Katyńskie”, nr 2), s. 77.

${ }^{40}$ Potwierdził to Niemiecki urzędowy materiat..., s. 42.

${ }^{41}$ Ibidem, s. 50.
} 
Kluczowe zeznanie zapisano pod datą 5 IV 1943 r. w Gniozdowie ${ }^{42}$, występującym jako „miejsce postoju” - jak wiemy dzisiaj - jednostki wojskowej Tajnej Policji Polowej. Podał w niej jedyny raz dzienną datę swojego urodzenia oraz wymaganych $\mathrm{w}$ takich przypadkach kilka danych o sobie. W zeznaniu występował jako kawaler, z zawodu tokarz, zamieszkały w Nowych Batiokach (obwód smoleński), dom nr 119, bezpartyjny, od lipca 1942 r. członek rosyjskiej Służby Porządkowej (niem. russ. Ordnungsdienst) ${ }^{43}$. Podczas trzeciego zeznania (patrz dalej) dodał też, że jest wyznania grekokatolickiego (griechisch-katholischer Religion), choć oznaczało to najpewniej wyznanie prawosławne. $\mathrm{W}$ drugim chronologicznie zeznaniu, na podstawie wiadomości własnych i usłyszanych od rodziców, Kriwoziercew opisał przeznaczenie terenu kaźni w Kozich Górach, wykorzystywanego do egzekucji przez Czekę i jej następców od 1918 r., ogrodzenie terenu w 1931 r. i wybudowanie tam daczy w 1934 r. Podał też precyzyjnie lata, w których wykonywano na tym terenie egzekucje (1918-1929 i od 1940 r.). Mogło to oznaczać, co sugerował świadek, że w tym czasie ogrodzona dla potrzeb OGPU-NKWD część lasu katyńskiego służyła wyłącznie jako teren wypoczynkowy. W odniesieniu do zbrodni katyńskiej Kriwoziercew zeznał: „Od 1940 r. teren Kozich Gór był ponadto strzeżony przez wartowników i psy. W marcu i kwietniu $1940 \mathrm{r}$. do Gniezdowa dotarło wiele wagonów towarowych z jeńcami, którzy byli następnie ładowani do ciężarówek więziennych, nazywanych przez ludzi «czarnymi krukami» [ros. czornyj woron - A.B.]. Samochody te jechały ze stacji Gniozdowo w kierunku Katynia"44. Dodał też, że nie słyszał strzałów oddawanych podczas egzekucji.

Zeznanie jest też istotne $\mathrm{z}$ punktu widzenia opisu terenu egzekucji. Kriwoziercew wskazał, że w czasie, gdy teren nie był ogrodzony, a więc przed 1931 r., podczas chodzenia na grzyby „starsi wielokrotnie pokazywali mu świeże groby" 45 .

Podczas zaprzysiężenia złożonych wcześniej zeznań, co miało miejsce w Gniezdowie 18 IV 1943 r., Kriwoziercew dodał, że przypomniał sobie, jak w sobotę 17 bądź 18 IV 1940 r. ${ }^{46}$ „z Lasu Katyńskiego w kierunku

${ }^{42}$ F. Goetel, Czasy wojny..., s. 270. Pełny tekst zeznania, bez wskazania miejscowości, w: Niemiecki urzędowy materiat..., s. 47.

${ }_{43}$ Niemiecki urzędowy materiat..., s. 47. Jak mówił w jednej z relacji Kriwoziercew, wstapił do Ordnungsdienstu, „złożonego z ludności miejscowej. [...]. My ludzie poglądów antysowieckich staraliśmy się wtedy opanować Ordnungsdienst, w obawie, aby nie wtargnęli do niego bolszewicy i nie działali na naszą szkodę". F. Goetel, Czasy wojny..., s. 267.

${ }^{44}$ Ibidem.

45 Niemiecki urzędowy materiat..., s. 47.

${ }^{46}$ Sobota wtedy przypadała 20 kwietnia 1940 r. Kronika XX wieku, s. 552. Nieścisła jest także data wydarzenia, która w relacji Kriwoziercewa Mackiewicz przesuną tydzień później (23 czy 24 kwietnia; Zbrodnia katyńska w świetle dokumentów..., s. 205), precyzując ponadto, że ostatni transport Kriwoziercew zaobserwował 17 kwietnia. Ibidem. 
Smoleńska jechało około 10 ciężarówek załadowanych do pełna walizkami, torebkami, workami z bielizną i płaszczami. W każdej ciężarówce siedziało dwóch czekistów"47.

Po ucieczce z rodzinnych okolic Kriwoziercew złożył jeszcze kilka razy uzupełnione zeznania. Do czasu formalnego upadku komunizmu w ZSRR (8 XII 1991 r.) opublikowane zostały wspomniane na początku niniejszego artykułu dwa zeznania, złożone prawie na pewno przed władzami II Korpusu Polskiego, stacjonujacego w Ankonie, spisane przez Mackiewicza i Goetla i wydane odpowiednio po niemiecku w 1948, po angielsku w 1951 (Mackiewicz) i w 1955 r. (Goetel), jak również przez tych samych autorów w formie artykułów. Jak była mowa, w 1948 r. ukazało się także pierwsze wydanie Zbrodni katyńskiej $w$ świetle dokumentów, zawierające rozszerzone zeznania Kriwoziercewa, złożone władzom polskim w październiku 1946 r., a także dwa artykuły Goetla i Mackiewicza, poświęcone śmierci Kriwoziercewa w Wielkiej Brytanii w październiku $1947 \mathrm{r}$.

Rozszerzone po wojnie zeznania Kriwoziercewa zawierają nie tylko dokładniejszy opis wydarzeń, związanych z odkryciem zbrodni w lesie katyńskim, ale też znacznie szerzej informują o represjach wobec rodziny Kriwoziercewa i stanie jego umysłu. Co jednak istotne, inkorporuja także zeznania innych świadków, które znalazły się w urzędowym materiale niemieckim sprawy katyńskiej, wydanym w 1943 r. Kriwoziercew pozostał jedynym, który złożył upublicznione zeznania na Zachodzie (we włoskiej Ankonie), chociaż najpewniej - o czym dalej - nie był jedynym świadkiem podobnych wydarzeń spośród miejscowych, któremu udało się zbiec na Zachód. Zeznania Kriwoziercewa, publikowane w beletrystycznej formie przez Goetla i Mackiewicza, zostały upublicznione po jego śmierci.

Odnośnie do tła i wydarzeń, poprzedzających zbrodnię oraz tych, które następowały w jego życiu po złożeniu zeznań, Kriwoziercew dodał wiele szczegółów z życia osobistego, rozwijając informacje, które zeznał przed Niemcami ${ }^{48}$. Wskazał pośrednio także motywy złożenia wtedy zeznań oraz dalszego postępowania: „Każdy z nas zresztą doskonale sobie zdawał sprawę, że $\mathrm{w}$ ten sposób podpisujemy na siebie wyrok ze strony władzy sowieckiej. A na froncie Niemcom działo się nie najlepiej..." - powiedział Mackiewiczowi ${ }^{49}$.

Identyczne argumenty Kriwoziercewa znane są zatem również w odniesieniu do motywów ucieczki przed Armią Czerwona, podobnie zreszta jak wydarzenia, które w związku z tym opisał. Był oczywiście pewien, że trzeba uciekać, zauważając ponadto, że już przed ponownym wejściem Armii Czerwonej

\footnotetext{
${ }^{47}$ Niemiecki urzędowy materiat..., s. 57.

${ }^{48}$ Pośrednio okazało się np., że podczas niemieckiej okupacji powrócił do swojego domu we wsi Nowyje Batioki (nr 119), w którym, jak była mowa, po powrocie z wojska nie mógł już mieszkać. Por. adres Kriwoziercewa w jego zeznaniach. Ibidem.

${ }^{49}$ J. Mackiewicz, Katyń..., s. 148.
} 
próbowano skłonić osoby, zeznające dla Niemców, do pozostania na miejscu. Oprócz złożenia zeznań do wydanego niemieckiego raportu Iwan Kriwoziercew występował jako świadek przed komisją międzynarodową i organizowanymi przez Niemców licznymi wycieczkami na groby, pełnił też - jak twierdził funkcję dostarczającego robotników na miejsce robót ekshumacyjnych. Był również członkiem wspomnianej już, utworzonej przez Niemców, lokalnej Służby Porządkowej (Ordnungsdienst). Wobec sowieckich władz okoliczności takie bardzo obciążały: za każdy taki czyn orzekano w tym czasie karę śmierci. Kriwoziercew miał w pamięci podjęte przez bolszewików surowe represje wobec rodziny za bez porównania mniejsze przewinienia.

Podając fakty ze swojej ucieczki, Kriwoziercew kreślił jej spontaniczny obraz. Uciekło zreszta, jak zauważył, wiele osób związanych z ujawnieniem mordów w lesie katyńskim, dbając wcześniej o zorganizowanie swojego wyjazdu. Nie zdołał ujść razem ze swoim prawdopodobnie przyrodnim bratem $^{50}$, także zeznającym w niemieckim raporcie, Iwanem Andriejewem, który wyjechał na jedyne wolne miejsce $\mathrm{w}$ samochodzie znanego dobrze obu tłumacza Geheime Feldpolizei ${ }^{51}$. Można domniemywać, że bracia planowali zatem ucieczkę tylko we dwóch ${ }^{52}$, jednak tuz przed przełamaniem frontu, 24 IX 1943 r., Kriwoziercew oddalił się z miejsca zamieszkania wraz z matka i siostrzenica, upraszając, jak pisał, niemiecką kolumnę samochodowa ${ }^{53}$ albo też, jak podawał w innym miejscu, wyszedł na szosę i poprosił niemieckiego żandarma, by zatrzymał dlań jakiś jadący na Zachód samochód (prawdopodobnie za łapówkę).

Po wkroczeniu do Smoleńska i lasu katyńskiego oddziałów sowieckich zorganizowano od razu poszukiwania świadków ujawnienia zbrodni, którzy przekazali informacje Niemcom. Przesłuchaniu poddano aż 95 osób. Represje dotknęły np. Iwana Andriejewa, ps. Rumba, który został skazany na 25 lat więzienia (zrehabilitowany w 1956 r.). Dwóch innych świadków (z sześciu), którzy złożyli zeznania dla Niemców, zamieszczone w ich raporcie, Kuźma Godunow i Grigorij Silwiestrow, zmarło nagle w 1943 r. ${ }^{54}$

${ }^{50}$ Kriwoziercew nie wspominał o tym pokrewieństwie. Wiadomo jednak, że Iwan Andriejew był siostrzeńcem sołtysa wsi Nowyje Batioki, Matwieja Zacharowa (por. Niemiecki urzędowy materiat..., s. 59) i z kolei wujem Iwana Kriwoziercewa (Zbrodnia katyńska w świetle dokumentów..., s. 209; J. Mackiewicz, Katyń..., s. 157).

${ }^{51}$ J. Mackiewicz, Katyń..., s. 158. Z przekazu wynika, że w takim wypadku Iwan Andriejew pozostawiłby w domu żonę, z która jednak, jak jeszcze będzie mowa, Kriwoziercew zobaczył później brata w Mińsku. Niemiecki urzędowy materiał..., s. 59. Por. także spotkanie obu braci po ucieczce: J. Mackiewicz, Katyń..., s. 157.

${ }^{52} \mathrm{~W}$ innym miejscu Kriwoziercew podał, że Iwan Andriejew, którego spotkał potem w białoruskim Mińsku, przebywał razem z żoną i tam urodziła im się córka.

${ }^{53}$ J. Mackiewicz, Katyń..., s. 158.

${ }^{54}$ N.S. Lebiediewa, Komisja specjalna i jej przewodniczacy Burdenko, w: Zbrodnia katyńska między prawda i ktamstwem, red. M. Tarczyński, Warszawa 2008 („Zeszyty Katyńskie”, nr 23), w szczególności s. 62-65. 
W ramach przygotowania fałszywych świadków sowieckich Komisja Burdenki posłużyła się fortelem podstawienia jako świadków osób o tych samych nazwiskach, jak zeznający wcześniej dla Niemców, z innym inicjałem imienia. Ludzie ci mogli być krewnymi świadków zaprzysiężonych wcześniej przez Niemców, nawet jeżeli w stosunkach wiejskich pokrewieństwo osób, noszących te same nazwiska, nie jest reguła. Tak więc obok pozostałego na miejscu Parfiona Kisielowa raport Komisji Burdenki zawiera, fałszywe oczywiście, zeznania jego syna, Wasilija oraz zeznania Michaiła G. Kriwoziercewa, nie zaś Iwana o tym samym nazwisku. Mistyfikacja mogła odnieść pożądany przez władze sowieckie skutek. Nawet najobszerniejsze współczesne polskie wydawnictwo źródłowe, dotyczące zbrodni katyńskiej, błędnie utożsamia obie postaci: Iwana i Michaiła Kriwoziercewów ${ }^{55}$.

Parfion Kisielow i Iwan Kriwoziercew byli jednymi z najważniejszych świadków raportu niemieckiego. Michaił Kriwoziercew przyznał się do nieprawdziwych zeznań w 1990 r. Nota bene wielu fałszywych sowieckich świadków odwołało wtedy swoje zeznania, złożone przed Komisją Burdenki, jako oczywiście wymuszone ${ }^{56}$.

Pozostaje oczywiście kwestia, ile zeznań, gdzie i kiedy złożył Kriwoziercew po ucieczce z rodzinnych okolic, a także - co ważniejsze - czy zeznania takie różnią się nieznacznie między sobą, zawierając różne i dodatkowe okoliczności ujawnienia zbrodni (okoliczności i fakty bezpośrednie) czy nawet fakty popełniania zbrodni - te ostatnie jednak tylko w formie okoliczności pośrednich. Jak już stwierdzono, zeznania Kriwoziercewa przytoczyli pierwotnie w swych książkach Ferdynand Goetel i Józef Mackiewicz.

Po oddaleniu się z miejsca zamieszkania uciekinier dotarł na krótko do białoruskiego Mińska, by następnie spotkać tam siostrę, która uciekła na własną rękę. Wspólnie, tzn. z matka, siostrą i sześcioletnią siostrzenica, dotarli pociagiem do Tłuszcza pod Warszawą ${ }^{57}$. Kriwoziercew spędził tam dwa tygodnie, a trzy następne w Siedlcach ${ }^{58}$.

Według dalszej opowieści Kriwoziercewa po pobycie w Siedlcach zgłosił się do pracy, zostając robotnikiem niemieckiego „sztabu batalionu kolejowego”. Nie wiadomo, czy otrzymał od kogoś pomoc w załatwieniu takiej pracy, nie był bowiem robotnikiem cywilnym. Mógł także wylegitymować się legitymacja Ordnungsdienstu, do którego wstapił już w lipcu 1942 r. Najpewniej jednak to nastapiło. Prawdopodobnie Niemcy, z którymi się ewakuował, poradzili, jak ma się zwrócić o pracę do Wehrmachtu jako pracownik cywilny wojska.

${ }^{55}$ Zob. Katyń. Dokumenty zbrodni, t. IV: Echa Katynia, kwiecień 1943 - marzec 2005, red. nauk. W. Materski i in., oprac. W. Materski i in., Warszawa 2006, indeks nazwisk, s. 603, gdzie jako Kriwoziercow (tak w pisowni książki) występuje jedynie „Iwan G[rigorijewicz]”.

${ }^{56}$ Szerzej zob. N.S. Lebiediewa, op. cit.

${ }_{57}$ Zbrodnia katyńska w świetle dokumentów..., s. 209.

${ }^{58}$ Ibidem. Goetel wspominał bardziej ogólnie, że Kriwoziercew spędził wtedy w Polsce pięć tygodni. F. Goetel, Czasy wojny..., s. 272. 
Jeśli tak było, Mackiewicz i Goetel nie podali tego faktu z obawy przed utrata wiarygodności świadka. W jednej z notatek służbowych, zachowanych w archiwach Instytutu Polskiego i Muzeum im. gen. Sikorskiego w Londynie (IPMS), znalazła się informacja, że ewakuować się Kriwoziercewowi z miejsca zamieszkania pomogli Niemcy ${ }^{59}$. Może być to jednak tylko przypuszczenie osoby sporządzającej taką notatkę.

Wysłany następnie w ramach nowych obowiązków do białoruskiego Mińska Kriwoziercew spotkał tam swoich ziomków: Iwana Andriejewa i Jewgienija Siemianienkę wraz z jego matką Emilia, Polka, z d. Kozłowską. Wszyscy uciekli przed bolszewikami. W przeszłości Kriwoziercew dużo rozmawiał z nimi o miejscu straceń w Kozich Górach, a Siemianienko był tłumaczem miejscowych wobec odwiedzających ekshumacje delegacji, o co prosili Niemcy, mając również swojego tłumacza.

Kriwoziercew nie wiedział, co stało się później z jego znajomymi (o czym jeszcze będzie mowa). Wrócił do Łowicza i pod Łódź, gdzie batalion kolejowy został rozformowany. Według jego relacji został następnie robotnikiem cywilnym, otrzymujac niemiecka kartę pracy. Występował w niej jako bezpaństwowiec czy też dokładniej jako człowiek o niejasnej przynależności państwowej, czyli obywatelstwie (Staatsangehörigkeit ungeklärt). Jak stwierdził potem odbierający od niego pierwsze zeznanie polski oficer: „Niemcy wystawiali Rosjanom, którzy byli dobrze przez nich widziani dokumenty z podaniem Staatsangehörigkeit ungeklärt lub Staatenlos [bezpaństwowiec - A.B.], aby im umożliwić życie bez prześladowań” ${ }^{60}$. Jako dawny członek Ordnungsdienstu choć nie wiadomo, kiedy przestał nim być - Kriwoziercew był takim człowiekiem. Mógł też korzystać z innej opieki Niemców, choć brak do tego wskazań.

Kriwoziercew pracował więc pod Berlinem ${ }^{61}$, a wobec zbliżania się końca wojny wyruszył wraz z matką na Zachód, nie chcąc dostać się w ręce Armii Czerwonej. Oznacza to, że porzucił pracę, co mogło wiązać się z dotkliwymi represjami. Wcześniej prawdopodobnie musiał uzyskać poparcie Niemców do podjęcia pracy w okolicach Berlina, chociaż mógł także zostać przerzucony do takiego zajęcia, a wobec końca działań wojennych w ramach panujących nieporządków wyruszył po prostu na tułaczkę. Jest to jednak mniej prawdopodobne.

\footnotetext{
${ }^{59}$ AIPMS, kol. 13/3, Uroczyste zatwierdzenie, 31 maja 1945, k. nlb. Kriwoziercew oświadczył w nim: „Z chwila postępu wojsk rosyjskich zostałem wysłany przez Niemców do Niemiec, gdzie ostatnio pracowałem jako pracownik kolejowy w Berlinie. Przed zajęciem Berlina przez Rosjan uciekałem w kierunku zachodnim i zgłosiłem się do oficera polskiego mjr. W. Grubert. Był on pierwszym przedstawicielem alianckim, którego spotkałem”. Ibidem. Wiemy już, że ostatnie zdanie nie było zgodne z prawdą. Kolejne fragmenty dokumentu zostaną omówione w dalszej części artykułu.

${ }^{60}$ Ibidem, P. Jankowski, Uwagi do protokołu Iwana Kriwoziercewa, spisanego w Niemczech w dniu 31 maja 1945 roku, 21.11.1951 r., k. 37d.

${ }^{61}$ Ta i dalsze informacje za: Zbrodnia katyńska w świetle dokumentów..., s. 209.
} 
Po ponownej ucieczce musiał też - jak pisał - zostawić matkę i prawdopodobnie siostrę z siostrzenica niedługo po wyruszeniu, w okolicach Berlina ${ }^{62}$. Pod Hamburgiem spotkał rosyjskiego jeńca występującego jako Miszka, z którym zaczęli wędrować wspólnie, przedostając się do Bremy. Tam zgłosił się do armii amerykańskiej w komendzie miasta ${ }^{63}$, komunikując, że chce złożyć ważne zeznanie w sprawie mordu w Kozich Górach. Wobec braku zainteresowania przełożonych, do których udał się po instrukcje w tej sprawie, Amerykanin z komendy miasta poradził zwrócić się do Armii Czerwonej, omal nie wydając Kriwoziercewa czynnikom sowieckim. Po tym doświadczeniu Kriwoziercew, jak podawał, zaczą z kompanem szukać kontaktu z Polakami. Dostał się do obozu ludności polskiej pod Meppen, niedaleko obecnej granicy holenderskiej, gdzie skontaktował się wreszcie z oficerem 2 Korpusu, nazwiskiem Sołtys (prawdopodobnie ppor. Sołtyk) ${ }^{64}$, który z kolei skomunikował świadka ze sztabem Wojska Polskiego, a ściślej 1 Dywizji Pancernej ${ }^{65}$, przebywającym w tym mieście.

W Meppen Kriwoziercew złożył czynnikom wojskowym Polskich Sił Zbrojnych na Zachodzie identyczne $\mathrm{w}$ treści zeznania ${ }^{66}$, a także kilka dalszych, których w efekcie, do dnia dzisiejszego, zewidencjonowano sześśc ${ }^{67}$. Odebrali je prokuratorzy wojskowi bądź pracownicy prokuratury wojskowej. Podobnie jak wcześniej władzom niemieckim, nastapiło ich uroczyste zatwierdzenie pod przysięga, potwierdzające odpowiedzialność za złożone słowa ${ }^{68}$. Przy prowadzonym w 1951 r. postępowaniu po śmierci Kriwoziercewa dokonujący streszczenia zeznań polski urzędnik stwierdził, że odbierający zeznanie Kriwoziercewa (mjr Grubert) uznał (bądź usłyszał):

${ }^{62}$ Nie oznacza to jednak, że matka i siostrzenica Kriwoziercewa straciły życie, jak pisze ostatnio w książce o Katyniu niemiecki dziennikarz. Th. Urban, op. cit., s. 422-423. Jak już stwierdzono, podobnie jak cytowana książka Eugenii Maresch, książka Thomasa Urbana zawiera wiele nieścisłości na temat Kriwoziercewa.

${ }^{63}$ „Za tłumacza - mówił Kriwoziercew - służył mi wówczas inny Rosjanin, inżynier, któregośmy się [z Miszką - A.B.] później pozbyli”. Zbrodnia katyńska w świetle dokumentów..., s. 210.

${ }^{64}$ Nazwisko Sołtys podał F. Goetel (Czasy wojny..., s. 273), lecz w dokumentach występuje ppor. Sołtyk (AIPMS, kol. 13/3, P. Jankowski, Uwagi do protokołu Iwana Kriwoziercewa, spisanego w Niemczech w dniu 31 maja 1945 roku, 21.11.1951 r., k. 37d). Natomiast według różnorakich wykorzystanych w prezentowanym artykule danych archiwalnych oficerem łącznikowym, który przejął następnie Kriwoziercewa, był mjr Wiktor Grubert, zmarły w Londynie w 1946 r. po operacji żołądka. Ibidem; nazwisko Gruberta bez Sołtyka zob. też: E. Maresch, op. cit., s. 81.

${ }^{65}$ AIPMS, Katyń, kol. 13/3, Notatka służbowa (bez daty), dotycząca Iwana Kriwoziercewa. Materiały w sprawie Iwana Kriwoziercewa (w tekstach używane nazwisko „Kriwoziercow”), częściowo nienumerowane, często w kilku egzemplarzach (np. kalki).

${ }_{66}$ Dwa zeznania, powtarzając literalnie (ostatnie w skróconej wersji), zamieszcza E. Maresch, op. cit., s. $92-112$.

${ }_{67}$ Zob. J. Platajs, Zbrodnia katyńska. Zeznania świadków przed polskimi sqdami wojskowymi 1943-1946, Gdańsk 2016, s. 231-238.

${ }^{68}$ AIPMS, kol. 13/3, Uroczyste zatwierdzenie, 31 maja 1945, k. nlb. Odbiorca oświadczenia był mjr W. Grubert. 
że wszystko to, co o Katyniu wiedział, zameldował Niemcom, którzy sami oraz różne sprowadzane przez nich komisje jego zeznania protokołowały oraz ogłaszały drukiem w niemieckich wydawnictwach propagandowych. Dlatego - stwierdza p. Grubert w protokole, który z Kriwoziercowem on spisał, nie interesował się szczegółami, a ograniczył się tylko do jak najkrótszego stwierdzenia danych personalnych Kriwoziercewa oraz faktu, że wie o masakrze katyńskiej, kiedy i kto to zrobił, itp. ${ }^{69}$

Przekonaniu takiemu przeczą jednak zawarte w tych samych archiwaliach dokładne zeznania Kriwoziercewa. Zostały one podpisane na każdej stronie. Nie są to jednak, jak zauważano ostatnio, zeznania złożone przed Goetlem, a przed wojskowym wymiarem sprawiedliwości ${ }^{70}$. Zeznania takie składało na temat zbrodni katyńskiej wiele osób, mających z nią styczność, w latach 1943-1946 $6^{71}$. Wskazane archiwalia zawieraja takie właśnie relacje, w tym omówioną w niniejszym artykule dokumentację odebraną od Kriwoziercewa ${ }^{72}$. Prawie nikt z nich nie został jednak później wykorzystany w pracach komisji katyńskiej Izby Reprezentantów Stanów Zjednoczonych (tzw. Komisji Raya Maddena). Dotyczy to także świadków sowieckich, którzy uciekli jak Kriwoziercew (przede wszystkim Emilia i Jewgienij Siemianienko oraz Iwan Andriejew), o których ponoć władze brytyjskie wiedziały, że w 1945 r. przebywali na terenie Wielkiej Brytanii i byli znani władzom brytyjskim ${ }^{73}$.

Po złożeniu zeznań Kriwoziercew został skierowany do Ankony w środkowych Włoszech ${ }^{74}$, jednak jego relacje - przesłane drogą służbową najwyższym polskim władzom wojskowym (już 4 VI 1945 r. gen. Klemens Rudnicki przekazał zeznania szefowi sztabu Naczelnego Wodza, ministrowi spraw zagranicznych Adamowi Tarnowskiemu i Brytyjczykom ${ }^{75}$ - przeszły bez echa ${ }^{76}$. Odebrali tam także od niego zeznania wspominani wielokrotnie Goetel i Mackiewicz, którzy zamieścili je w swoich książkach. Pisarze różnili się w ocenie osoby i motywów działania Kriwoziercewa, podane przez nich relacje wyglądaja

${ }^{69}$ Ibidem, P. Jankowski, Uwagi do protokołu Iwana Kriwoziercewa, spisanego w Niemczech w dniu 31 maja 1945 roku, 21.11.1951 r., k. 37d.

${ }^{70}$ Por. E. Maresch, op. cit. O nieścisłościach w cytowanej książce była już mowa wcześniej.

${ }^{71}$ Szerzej zob. J. Platajs, op. cit.

72 AIPMS, Katyń, kol. 13/3, relacje w zbiorze 37, teczka z napisem „Kriwoziercow”. Jak już wskazano, materiały są z reguły nienumerowane, posiadając czasami na marginesach paginację 37 , z dodatkiem oznaczenia literowego.

${ }^{73}$ E. Maresch, op. cit., s. 327.

${ }^{74}$ F. Goetel, Czasy wojny..., s. 273; Zbrodnia katyńska w świetle dokumentów...

75 AIPMS, kol. 13/3, k. 37g; informację bez podania źródła zamieszcza też E. Maresch, op. cit., s. 79.

${ }^{76}$ Co ciekawe, przy zeznaniach, przetłumaczonych dla władz brytyjskich na język angielski i wysłanych przez gen. Klemensa Rudnickiego, ukryto personalia przesłuchujacego, tłumacza i protokolanta, przekreślając na pierwotnej wersji tekstu ich nazwiska i wprowadzając ołówkiem dane „N.N” i „X.Y”. AIPMS, kol. 13/3, Copy - Translation, Report of Interrogation of Witness, [z błędną data] 22 V 1945 r. Świadczy to oczywiście o obawach przed dostaniem się personaliów z zeznania w ręce sowieckie. 
jednak niemal identycznie (patrz wcześniej ${ }^{77}$ ). Są także niemal tożsame w wielu szczegółach z innymi relacjami, jakie w formie zeznań zdawał Kriwoziercew, poczynając od tych złożonych Niemcom i zamieszczonych - na pewno we fragmentach - w ich urzędowym materiale na temat zbrodni katyńskiej, opublikowanym przez Centralne Wydawnictwo NSDAP w Berlinie w 1943 r.

Do spopularyzowanych w cytowanych książkach Goetla i Mackiewicza zeznań Kriwoziercewa włączono w szczególności niektóre fakty z relacji innych świadków niektórych okoliczności, związanych pośrednio z popełnieniem i ujawnianiem zbrodni. Trudno dziś stwierdzić, czy nie dokonał tego sam Kriwoziercew, choć to mało prawdopodobne, biorąc pod uwagę, że obu pisarzom były na pewno znane zeznania świadków z raportu niemieckiego z 1943 r. Może to być zabieg Mackiewicza przygotowującego do druku swoja, choć anonimowa, książkę Zbrodnia katyńska w świetle dokumentów.

Współczesna analiza zeznań Kriwoziercewa pozwala więc nie tylko w niektórych miejscach je zweryfikować, ale też postawić pytania o kilka niejasności. Pierwszą nieścisłość stanowiło przekonanie, że rozstrzeliwań jeńców polskich w lesie katyńskim dokonywało „czeka mińskie”78, tj. funkcjonariusze Urzędu NKWD w stolicy Białoruskiej SRR. Plotka ta krążyła wśród miejscowej ludności i została powtórzona następnie przez Niemców, po rozpoczęciu przez nich krótkich badań nad zbrodnią katyńską w $1943 \mathrm{r} \cdot{ }^{79}$ Przyjęli ją po wojnie także inni badacze zbrodni, w szczególności Mackiewicz. Współcześnie wiemy, że rozstrzeliwań dokonywał zespół miejscowych funkcjonariuszy, tj. smoleńskiego Obwodowego Urzędu NKWD, bardzo niskiej rangi (kierowcy, nadzorcy i strażnicy komendantury $)^{80}$, pod kierownictwem komendanta tzw. więzienia wewnętrznego NKWD w Smoleńsku ${ }^{81}$, prawdopodobnie wtedy w stopniu kapitana bezpieczeństwa państwowego, Iwana Stelmacha $(1882-1957)^{82}$. Nie było

77 Warto też dodać, że Kriwoziercew zeznawał za każdym razem niemal to samo, rozbudowując niektóre wątki (głównie osobiste) wobec Goetla i Mackiewicza.

78 F. Goetel, Czasy wojny..., s. 264; J. Mackiewicz, Katyń..., s. 205.

${ }^{79}$ Szerzej zob. A. Bosiacki, op. cit., s. 17-18. Poszukiwania prowadzono bezskutecznie m.in. w przejętym przez hitlerowców archiwum NKWD w Mińsku z lat 1917-1938, co skutkowało wskazywaniem w propagandzie Rzeszy Niemieckiej (co ciekawe, z wyjatkiem Niemieckiego urzędowego materiatu...) fikcyjnych nazwisk funkcjonariuszy odpowiedzialnych za zbrodnię w lesie katyńskim. Nazwiska te funkcjonowały literaturze przedmiotu długo po wojnie, a w popularnym piśmiennictwie występują nawet obecnie. Niemiecki urzędowy materiat...

${ }^{80}$ N. Pietrow, op. cit., s. 74.

${ }^{81}$ Chodziło o więzienie odpowiedniego szczebla (w tym wypadku obwodu) urzędu NKWD, w odróżnieniu od innych więzień na analogicznym terenie.

${ }^{82}$ Dokładnie zob. N. Pietrow, op. cit., np. s. 70. Swianiewicz zapamiętał Stelmacha w mundurze z emblematami wojskowymi kapitana, który jako stopień był równy ze stopniem porucznika (lejtnanta) bezpieczeństwa państwowego. Pod koniec wojny (nie później niż w styczniu 1944 r., chociaż dokładna data nie jest znana) Stelmach awansował na majora bezpieczeństwa państwowego (do lipca 1945 r. odpowiednik pułkownika w wojsku). Zob. ibidem. 
wśród nich ani jednego funkcjonariusza delegowanego z Obwodowego Urzędu NKWD w Mińsku. Można przypuszczać, że bezpośrednio nadzorowali egzekucję nieliczni funkcjonariusze przybyli z Moskwy ${ }^{83}$, podobnie jak w innych głównych miejscach rozstrzeliwań (w Kalininie i Charkowie) ${ }^{84}$.

Druga wątpliwość w przekazie Kriwoziercewa stanowi zidentyfikowanie dwóch wykonawców mordu. Przed Niemcami w 1943 r. zeznanie takie złożył Andriejew, po wojnie szczegóły znalazły się jednak w przekazach Kriwoziercewa. Jeden z wykonawców zbrodni to nieznany z nazwiska funkcjonariusz Obwodowego Zarządu NKWD w Smoleńsku, pochodzacy z gminy Katyń, który do 1928 r. przez jakiś czas pełnił funkcję przewodniczącego rady wiejskiej w miejscowości Syrlipieckowo ${ }^{85}$ (nazwy tej, również w podobnym brzmieniu, nie zdołałem zidentyfikować; także na mapie) ${ }^{86}$. Funkcja enkawudzisty była znaczaca, miał bowiem odpowiadać za transporty przybywajace do Gniazdowa ${ }^{87}$. Drugi wykonawca zbrodni to miejscowy funkcjonariusz NKWD Akim Siergiejewicz Razuwajew, nazywany swojsko Kimem ${ }^{88}$. Otrzymał on wysoka nagrodę pieniężną za udział w zbrodni, za która, jak podawał w raporcie niemieckim Andriejew, kupił motocykl ${ }^{89}$.

Kriwoziercew przekazał, że Razuwajew hulał następnie i pił do nieprzytomności, razem z kolejnym wykonawcą zbrodni, kierownikiem garażu NKWD w Smoleńsku. Razuwajew według Kriwoziercewa był od 1937 r. kierowca jednego z samochodów-więźniarek (czornych woronow) ${ }^{90}$. Jak stwierdziłem $\mathrm{w}$ innym miejscu, problem jedynie $\mathrm{w}$ tym, że nikt o podobnych personaliach nie figuruje ani w spisie wykonawców zbrodni, ani w wykazie osób nagrodzonych przez Ławrientija Berię w 1940 r. ${ }^{91}$ Być może zatem Razuwajew nie należał do wykonawców zbrodni, a świadek pomylił nazwisko z drugim

${ }^{83}$ Jednym z nich był wizytujący obóz w Kozielsku i nadzorujący „rozładunek” jeńców na stacji w Gniazdowie do lasu katyńskiego podczas pobytu na stacji Swianiewicza, rozszyfrowany przez Nikitę Pietrowa, płk Iwan Stiepanow (1890-1953). Ibidem, s. 66-67.

${ }^{84}$ Najwięcej funkcjonariuszy z Moskwy skierowano do Kalinina (dawny i obecny Twer), na czele z głównym katem Stalina, Wasilijem Błochinem (zob. ibidem), co wiązało się z największą liczbą przeznaczonych do zastrzelenia (trudno w tym wypadku pisać o rozstrzelaniu) więźniów z obozu w Ostaszkowie.

85 J. Mackiewicz, Katyń..., s. 149.

${ }^{86}$ Powoduje to niemożność zidentyfikowania personaliów tego funkcjonariusza NKWD, także na podstawie starannie zrekonstruowanych przez Nikitę Pietrowa biogramów wykonawców zbrodni na jeńcach z Kozielska. N. Pietrow, op. cit., s. 177-398.

87 Ibidem.

${ }^{88}$ W tekście Mackiewicza określany błędnie jako Jakim Razuwajew. J. Mackiewicz, Katyń...; por. także dalej.

${ }^{89}$ Dokładniej: Andriejew zauważał, że za egzekucje Razuwajew otrzymał nagrodę i pieniądze, co w relacji, podanej przez Mackiewicza, doprecyzował Kriwoziercew.

${ }^{90}$ J. Mackiewicz, Katyń...

${ }^{91}$ Niemiecki urzędowy materiat..., s. 58. Listę nagrodzonych (ułożoną niealfabetycznie) zob. N. Pietrow, op. cit., s. 147-155. 
niezidentyfikowanym funkcjonariuszem NKWD. Najbardziej prawdopodobne jest jednak, że Razuwajew rzeczywiście należał do wykonawców zbrodni katyńskiej, z jakiegoś powodu jednak jego nazwisko nie trafiło na listę nagrodzonych. W odnalezionych przeze mnie ostatnio wyrywkowych danych Razuwajew jako młodszy lejtnant bezpieczeństwa państwowego był w $1942 \mathrm{r}$. komendantem Oddziału Specjalnego (Osobogo Otdieta) NKWD walczącej na froncie 3 Armii (nie zdołałem ustalić wyższego związku taktycznego) ${ }^{92}$. Wszystko więc się zgadzało. Jak stwierdził Iwan Andriejew ${ }^{93}$, Akim Razuwajew został ewakuowany przez Sowietów po ataku na ZSRR, a co ważniejsze, do obowiązków Razuwajewa jako pracownika komendantury należało m.in. wykonywanie egzekucji. Zeznanie na ten temat było więc prawdziwe, a do ustalenia pozostaja personalia dwóch innych opisywanych przez mieszkańców wykonawców zbrodni. Zgadza się także wywnioskowanie przez nich czy może tylko przez Kriwoziercewa, podającego, że kilka razy rozmawiał z Razuwajewem, że „liczba mordujących, zrekrutowana ponoć z ochotników [...] wynosiła nie więcej niż 50 osób" ${ }^{94}$.

Ostatnia kwestia, związana z osobą Kriwoziercewa, jest tajemnica jego śmierci. Mackiewicz i Goetel, szczególnie zaś pierwszy z nich, poświęcili tej sprawie odrębne artykuły. W mniejszym stopniu sprawa powraca także w innych publikacjach, a ostatnio nakręcono również poświęcony temu zagadnieniu brytyjski film fabularny.

Najdokładniej sprawę śmierci Kriwoziercewa omówił Mackiewicz. Jak okazuje się z przeprowadzonych przeze mnie badań archiwalnych, artykuł Mackiewicza podsumowuje wyniki dochodzenia prowadzonego przez Oddział Wywiadowczy Sztabu Naczelnego Wodza (dawny Oddział II), którego akta, być może niekompletne, ale prawie zupełne, biorąc pod uwagę treść późniejszego tekstu Mackiewicza, zostały zdeponowane w Archiwum IPMS ${ }^{95}$. Zawierają one

${ }_{92}$ Rozkazem z 6 XI 1942 r. młodszy lejtnant bezpieczeństwa państwowego Akim Siergiejewicz Razuwajew (komendant OO NKWD 3 Armii) został nagrodzony medalem „Za wojennyje zasługi”. Prikaz wojskam 3 armii № 66/n ot 06.11.1942, https://nkvd.memo.ru_06.11.1942 (dostęp: 24 VII 2020). W odróżnieniu od innych wykonawców mordu na jeńcach z Kozielska nie figuruje jednak $\mathrm{w}$ bazach danych pracowników NKWD, zgromadzonych przez Stowarzyszenie Memoriał w Moskwie (trzy osoby o identycznym nazwisku nie spełniaja kryterium terytorium wyszukiwania). Zob. Kadrowyj sostaw organow gosudarstwiennoj biezopastnosti SSSR 1935-1939.

${ }_{93}$ Niemiecki urzędowy materiat..., s. 58.

${ }^{94}$ Pietrow szacuje liczbę oprawców na ok. 36 osób. N. Pietrow, op. cit., s. 160. Opuszczony fragment $\mathrm{w}$ przytoczonym cytacie dotyczy przekonania, że wykonawcy egzekucji rekrutowali się z NKWD w Mińsku, co jak wskazałem wcześniej, jest przekonaniem nieprawdziwym.

${ }_{95}$ AIPMS, Katyń, kol. 13/3, materiały w sprawie Iwana Kriwoziercewa (w tekstach używane nazwisko „Kriwoziercow”), częściowo nienumerowane (prawdopodobnie w zbiorze gromadzonych przez Oddział Wywiadowczy Sztabu Naczelnego Wodza relacji katyńskich relacja nr 37 i dalsze oznaczenia literowe), często w kilku egzemplarzach (np. kalki). 
również kilka informacji, których Mackiewicz nie podał w swoim artykule, a co nastapi w prezentowanym tekście.

Po złożeniu zeznań przed organami polskiego wojskowego wymiaru sprawiedliwości, a następnie prawdopodobnie także Goetlowi i Mackiewiczowi, Kriwoziercew rozpoczą pracę w $\mathrm{PCK}^{96}$. Biorąc pod uwagę kwalifikacje, został najpewniej zatrudniony jako robotnik. Podjęto też działania zmierzające do przeniesienia świadka do Anglii. Dbając o poufność, Kriwoziercewowi i całej sprawie, związanej z jego ochrona ${ }^{97}$ i złożonymi zeznaniami ${ }^{98}$, nadano kryptonim Kostar. Szef Oddziału Wywiadowczego Sztabu Naczelnego Wodza, płk (później gen. brygady) Stanisław Gano 28 VI 1946 r. rozpoczął od przesunięcia, jak pisał, Kriwoziercewa do II Korpusu ${ }^{99}$. Ostatecznie jednak Kriwoziercew przyjechał do Wielkiej Brytanii jako pracownik PCK ${ }^{100}$.

Przerzut Kriwoziercewa do Wielkiej Brytanii organizował Oddział Wywiadowczy Sztabu Naczelnego Wodza, który próbował gromadzić materiały zwiazane ze sprawą katyńska już od 1943 r. Za zgodą władz polskich razem z nim podróżował jego przyjaciel, którym jednak był już nie przebywający wcześniej w Ankonie nieznany nazwiska Miszka, a pojawiajacy się jako marynarz, niepodający z kolei najczęściej imienia niejaki Jan Chomiuk. Występował on pod tym właśnie nazwiskiem, natomiast Kriwoziercewowi nadano nowa tożsamość. Otrzymał teraz dokumenty na nazwisko „Michał Łoboda, rzekomo urodzony 6 czerwca 1916 w Wilejce, na Wileńszczyźnie"101, z zawodu kowal ${ }^{102}$.

W cytowanej notatce, sporządzonej na potrzeby władz podejmujących decyzje, zaznaczono:

${ }^{96}$ Ibidem, Niepodpisana Notatka służbowa [b.d.], dotycząca Iwana Kriwoziercewa, materiały w sprawie Iwana Kriwoziercewa, k. nlb.

${ }^{97}$ Ibidem, Pismo z-cy Szefa Sztabu Głównego, płk (St.) Gano do II Korpusu na ręce płk Protasewicza z dnia 28 czerwca 1946 r. z prośbą o „opiekę w myśl ustnego porozumienia” przekazanego w najbliższym czasie 1 Dywizji Pancernej świadka „Kostar”, k. 37f.

98 Jak była już mowa, przy zeznaniach, przetłumaczonych dla władz brytyjskich na język angielski i wysłanych przez gen. Klemensa Rudnickiego, ukryto personalia przesłuchującego, tłumacza i protokolanta, przekreślając na pierwotnej wersji tekstu ich nazwiska i wprowadzajac ołówkiem dane „N.N” i „X.Y”. Ibidem, Copy - Translation, Report of Interrogation of Witness, z błędną datą $22 \mathrm{~V} 1945 \mathrm{r}$.

${ }^{99}$ Ibidem, Pismo z-cy Szefa Sztabu Głównego, płk (St.) Gano z dnia 28 czerwca 1946 r. do dowódcy I Dywizji Pancernej w sprawie przesunięcia do II Korpusu świadka w sprawie „Kostar”, k. 37e.

100 Ibidem, Notatka służbowa.

101 J. Mackiewicz, Tajemnicza śmierć Iwana Kriwoziercowa, głównego świadka zbrodni katyńskiej, „Wiadomości” R. VII, (Londyn) 20 IV 1952, nr 15-16 (315-316), http://retropress.pl/ wiadomosci/tajemnicza-smierc-iwana-kriwoziercowa-glownego-swiadka-zbrodni-katynskiej/ (dostęp: 27 VII 2020), przedruk m.in. w: Katyń. Wybór publicystyki 1943-1988 i „Lista Katyńska”, Londyn 1988, s. 125. Autor niesłusznie pisze, że Kriwoziercew przybrał pseudonim, pomijając przy tym zaangażowanie polskich czynników oficjalnych w sprawę świadka.

102 AIMPS, Notatka służbowa. Stwierdzenie „z zawodu kowal” zostało pominięte w cytowanym przekazie Józefa Mackiewicza. 
Kriwoziercew jest w tej chwili jedynym żywym i mogącym swobodnie zeznawać świadkiem przywożenia oficerów polskich na stację Gniozdowo ${ }^{103}$ pod Katyniem na wiosnę 1940 roku. Jest również w tej chwili na Zachodzie nie niemieckim świadkiem na okoliczności odkrycia przez Niemców masowych grobów w Katyniu. Jest to świadek tym ważniejszy, że przez cały czas bez przerwy, od 1940 do 1943 mieszkał w okolicy, a po odkryciu grobów był zajęty przy odgrzebywaniu zwłok, oraz był przesłuchiwany i wypytywany przez rozmaite komisje i wycieczki, które zjeżdżały do Katynia, m.in. przez grupę jeńców wojennych, oficerów brytyjskich, przywiezionych tam przez wojska niemieckie.

Wymienieni - konkludował raport - mogliby być bez trudności zatrudnieni w życiu cywilnym w ramach obecnej akcji, prowadzonej dla polskich uchodźców. Wstępnym jednak warunkiem jest wyrobienie dla nich papierów i dowodów tożsamości. Z odpowiednim wnioskiem wystapił przed kilku tygodniami Wydział Rodzin Wojskowych (Mjr Kołoskowicz) ${ }^{104}$.

Mackiewicz podał, że jesienią 1946 r. Kriwoziercew przybył do Wielkiej Brytanii do obozu dla uchodźców, otrzymujac faktyczny status dipisa, czyli osoby przemieszczonej z własnego kraju (displaced person), wymagajacej pomocy społecznej do powrotu bądź emigracji. Goetel wspominał, że wyjechał z Kriwoziercewem do Anglii z willi „Emilia” w Ankonie, gdzie wspólnie mieszkali $^{105}$. Wraz z nimi wyjechał prawdopodobnie również Mackiewicz, z tym że pisarze zatrzymali się w osobnych domach (być może wynajmując pokoje), a Kriwoziercew trafił do obozu dla dipisów we wsi West Chiltington, dystrykcie Horsham w hrabstwie West Sussex. Stamtąd w październiku 1947 r. Kriwoziercew przybył do podobnego obozu w Easton-in-Gordano w hrabstwie Somerset, $7 \mathrm{~km}$ na zachód od miasta Bristol. Sa to do dzisiaj małe miejscowości, na odludziu, jakich wiele znajduje się w Wielkiej Brytanii, stąd zakwaterowanie dipisów nie nastręczało prawdopodobnie żadnych problemów społecznych $\mathrm{z}$ lokalnymi zbiorowościami. Czego nie podał w pisemnych wynikach swego śledztwa Mackiewicz, oba obozy były obozami polskimi, przeznaczonymi prawdopodobnie zarówno dla szeregowych żołnierzy, jak i ludności cywilnej ${ }^{106}$.

O czym nie pisał Mackiewicz, a co wiadomo na podstawie zachowanych materiałów archiwalnych, powodem przeniesienia Kriwoziercewa i Chomiuka było złe zachowanie obu uciekinierów w obozie ${ }^{107}$. Po śmierci Kriwoziercewa w prowadzonym przez Polaków śledztwie stwierdzono:

${ }^{103}$ W tekście oczywiście „Gniezdowo”. W prezentowanym artykule starałem się podawać imiona, nazwiska i nazwy miejscowości w odczytanej obecnie przeze mnie prawidłowej formie.

104 AIPMS, Notatka służbowa.

105 F. Goetel, Czasy wojny..., s. 274.

106 Zob. cyt. wcześniej (przypis 83) nadesłany do Mackiewicza w języku angielskim list Savory'ego, stanowiący odpowiedź na pytanie Mackiewicza na temat losów Kriwoziercewa.

107 AIPMS, kol. 13/3, Michał Łoboda, Jan Chomiak [tak w oryginale - A.B.], notatka Oddziału Statystycznego Generalnego Inspektoratu PKPR do płk. J. Łunkiewicza z Komisji Likwidacyjnej MON (podpis nieczytelny) z 15 VII 1948 r. przy poszukiwaniach Kriwoziercewa. Oderwana paginacja $\mathrm{w}$ prawym górnym rogu. 
[zachowanie] było uciążliwe dla otoczenia, często się upijali i opowiadali wszystkim, że sa jedynymi świadkami zbrodni katyńskiej i z tego powodu rościli sobie prawa do wyjątkowego traktowania. Por. Heitzman (obecnie w USA) jeździł do obozu, po czym nastapiło pewne uspokojenie. Przez Wywiad Obronny [czyli kontrwywiad - A.B.] wystapiono do War Office z wnioskiem przeniesienia ich do Stowell Park nr. Cheltenham Glos.[ester] i podobno uzyskali tam pracę. Na początku 1948 r. zwrócono się do Wyw[iadu] Obr[onnego], mjr Czechowicza, aby ten dowiedział się, co się obecnie dzieje z Kriwoziercewem. Długie poszukiwania nie dały wyniku, prócz pogłosek, że Kriwoziercew został zabity, czy też popełnił samobójstwo. Policja brytyjska nie mogła, czy też nie chciała, dać bliższych wiadomości. W październiku r. 1948 zawiadomiły władze brytyjskie, że Kriwoziercew zmarł w r. 1947. Gdzie i w jakich okolicznościach - mimo nalegań mjr Czechowicza nie podano. Uzyskany adres Jana Chomiuka [...] okazał się nieaktualny ${ }^{108}$.

Na podstawie cytowanej notatki Mackiewicz pisał, że właśnie po przeniesieniu do ostatniego obozu Kriwoziercew „raptownie zniknął z powierzchni ziemi”. Jak się okazało, 30 X 1947 r. „jego ciało znaleziono w jednym z sadów. Badania, przeprowadzone 3 listopada $1947 \mathrm{w}$ komisariacie policji w Flax Bourton, Somerset, stwierdziły, że zmarły popełnił samobójstwo przez powieszenie" ${ }^{109}$. Śmierć nastapiła zatem po przeniesieniu z obozu uchodźców do pracy cywilnej, gdy Kriwoziercew jak gdyby znalazł się na wolności. Pomimo zakrojonych szeroko poszukiwań ciała Chomiuka nie odnaleziono ${ }^{110}$, co także może budzić podejrzenia. W artykule o śmierci Kriwoziercewa zdaje się je, prawdopodobnie słusznie, sugerować Mackiewicz.

Zacytowane $\mathrm{w}$ artykule Mackiewicza ustalenia policji nastapiły więc w wyniku żmudnych dociekań władz polskich (a na pewno nie tylko pisarza). Dochodzenie prowadziły czynniki polskie (na uchodźstwie) i brytyjskie. Te ostatnie, jak widać, nie od razu przekazały Polakom wiadomości o śmierci Kriwoziercewa, o czym wiadomo było jednak nie później niż w październiku 1948 r. ${ }^{111}$ Nic także nie wiemy o prowadzonym przez Brytyjczyków śledztwie w sprawie śmierci świadka. Jak będzie jeszcze mowa, świadczy też o tym brak jakichkolwiek brytyjskich archiwaliów na ten temat.

$\mathrm{Z}$ archiwaliów polskich $\mathrm{w}$ Londynie wynika natomiast, że jeszcze $\mathrm{w}$ listopadzie $1951 \mathrm{r}$. władze polskie na uchodźstwie nie wiedziały, co stało się z Kriwoziercewem ${ }^{112}$. Poszukiwania miały znaczenie dla rozpoczynającego się dochodzenia Komisji Izby Reprezentantów USA w sprawie popełnienia zbrodni

${ }^{108}$ Ibidem, Notatka. Dla gen. Andersa. Projekt, k. 37c.

109 J. Mackiewicz, Tajemnicza śmierć Iwana Kriwoziercowa...

110 AIPMS, kol. 13/3, Sprawa: Michał Łoboda [Kriwozierców - tak w oryginale - A.B.], Jan Chomiak [tak w oryginale - A.B.] - poszukiwanie, list Oddziału Statystycznego Generalnego Inspektoratu PKPR do płk. J. Łunkiewicza z Komisji Likwidacyjnej MON (podpis nieczytelny) z 29 X 1948 r., k. nlb.

${ }^{111}$ Ibidem.

112 Ibidem, P. Jankowski, Uwagi do protokołu Iwana Kriwoziercewa, spisanego w Niemczech w dniu 31 maja 1945 roku, 21.11.1951 r., k. 37d. 
katyńskiej, która chciała powołać Kriwoziercewa na świadka. Poszukiwania trwały zatem ponad trzy lata.

Indagowany podobno przez znanego dziennikarza i publicystę Juliusa Epsteina (1901-1975) w sprawie losu Kriwoziercewa, prawdopodobnie w związku z podjętym przez Komisję Izby Reprezentantów Stanów Zjednoczonych śledztwem w sprawie katyńskiej, Mackiewicz wystosował pismo do ministra spraw wewnętrznych, na które nie otrzymał odpowiedzi. Niestandardowe zachowanie jak na warunki brytyjskie zmusiło Mackiewicza do zwrócenia się do „jednego z wybitnych członków Izby Gmin” ${ }^{113}$. Z materiałów archiwalnych wynika, że był nim sir Douglas Lloyd Savory ${ }^{114}$ (1878-1969) z Ulsterskiej Partii Unionistycznej, autor wydanego w lutym 1944 r. Report on the Katyn Massacre, przypisującego winę za zbrodnię Sowietom, tuż po ogłoszeniu oficjalnego raportu ZSRR. Raport pozostał jednak tajny, tj. nieprzeznaczony do publikacji1 ${ }^{115}$. Jeszcze pod koniec lat osiemdziesiątych XX w. Savory został zapamiętany wśród emigrantów jako „wierny i oddany przyjaciel sprawy polskiej”"116.

Jak pisał dalej Mackiewicz, 29 II 1952 r. sir Savory otrzymał odpowiedź z Home Office, której oryginał, w postaci niewielkiej kartki, przechowywany jest zreszta do dziś w Archiwum Instytutu Polski i Muzeum im. gen. Sikorskiego w Londynie ${ }^{117}$. 5 III 1952 r. przekazał odpowiedź Mackiewiczowi. $\mathrm{W}$ publikowanej wersji odpowiedzi (w przypisie cytuję wersję anglojęzyczna $\mathrm{z}$ odnalezionego przeze mnie oryginału znajdującego się $\mathrm{w}$ Archiwum Instytutu Polski i Muzeum im. gen. Sikorskiego w Londynie) Mackiewicz pominął jedynie to, że Kriwoziercew przebywał w dwóch obozach polskich.

Już zwracając się do ministra spraw wewnętrznych, Mackiewicz stwierdził, że „nie ma żadnej wątpliwości że z rosyjskiego punktu widzenia, Kriwoziercow mieszkający w Anglii był osobą wielce niepożądaną; agenci zaś sowieccy, którzy

113 J. Mackiewicz, Tajemnicza śmierć Iwana Kriwoziercowa...

114 AIPMS, kol. 12/3 (Katyń), k. nlb.

115 Prof. L.D. Savory, MP, The Mass Murder of Polish Prisoners of War in Katyn, most secret. Not for publication, [London] March 1946, przedruk w: D.L. Savory, O rzezi w Katyniu, „Wiadomości”, (Londyn) 10 IV 1949, nr 15; Katyń. Wybór publicystyki..., s. 90-93.

${ }^{116}$ Katyń. Wybór publicystyki..., s. 90 (przypis).

117 AIMPS, Katyń, kol. 13/3, materiały w sprawie Iwana Kriwoziercewa (częściowo numerowane, oddzielna teczka). Oryginał tekstu, którego tłumaczenie zamieszcza w cytowanym artykule Mackiewicz, brzmi: „You wrote to the Home Secretary on the 5th February about Mr. Mackiewicz's enquiries relating to the Katyn Wood murders. I am afraid we have been unable to trace his earlier letter. Ivan Krivozhertzov, alias Michal Loboda, was at Stowell Park Hostel for a time, and in October 1947 went to another Polish camp at Easton-in-Gordano, Somersetshire. On 30th October, 1947, he was found dead in an orchard. An Inquest was held in on 3rd November, 1947, at the Police Station, Flax Bourton, Somerset, and the verdict returned was that the decessed committed suicide by hanging". Podpis (maszynopisem): Hugh Lucas-Tooth. W lewym górnym rogu w poprzek strony napisane ręcznie, prawdopodobnie przez Mackiewicza: „Home Office. List nadesłany przez prof. Savory". 
go zgładzili, mogli liczyć na spora nagrodę". Prosząc Savory'ego o interwencję, Mackiewicz wskazał także „na wagę, jaka posiada (czy posiadał?) Kriwoziercow dla wyjaśnienia i uwidocznienia przed całym światem rzeczywistych sprawców mordu katyńskiego. Zwróciłem jeszcze raz uwagę - pisał Mackiewicz - że tylko Sowietom i ich agentom zależeć może na unieszkodliwieniu tego świadka"118. Jest bowiem oczywiste, że Kriwoziercew nie miał motywu popełniania samobójstwa. Przeciwnie: obawa przed nieuchronną śmiercią stanowiła motyw jego ucieczki z rodzinnych stron, praktycznie bez jakichkolwiek środków do życia. Obawy o życie nie były oczywiście bezpodstawne, ojciec Kriwoziercewa został zastrzelony za dużo mniejsze przewinienia.

Pozorowane samobójstwo stanowiło natomiast jedna z metod, która w zabójstwach posługiwał się m.in. wywiad sowiecki (zapewne także inne). Spośród uznanych za zdrajców sowieckiego systemu zginęli tak m.in. czołowy niemiecki komunista Willi Münzenberg (1889-1940) i co ważniejsze, rezydent wywiadu i kontrwywiadu ZSRR (GRU) na całą Europę Zachodnia, Walter Kriwicki (właśc. Samuel Ginsberg, 1899-1941), znaleziony w zamkniętym od wewnątrz pokoju w hotelu „Bellevue” w Waszyngtonie w lutym $1941 \mathrm{r}$. z luźnymi zapiskami podobnymi do listów pożegnalnych. Chociaż w przypadku Münzenberga okoliczności śmierci moga wskazywać także na udział Gestapo, Kriwicki przed swą śmiercią ostrzegał, mówiąc, że jeśli znajdą list pożegnalny, nie mogą wierzyć, by popełnił samobójstwo ${ }^{119}$.

W przypadku Kriwoziercewa znacznie słabiej można uprawdopodobnić udział brytyjskich służb specjalnych w zorganizowaniu zabójstwa. Motywami przy tym mogły być determinacja, aby wystapić jako świadek, i częste chełpliwe opowieści o zbrodni katyńskiej na jeńcach z Kozielska przygodnym osobom, w wyniku czego, jak pisał Mackiewicz, ,wszyscy wiedzieli, nie zawsze ci, co o tym wiedzieć by powinni, że jest najważniejszym świadkiem największej zbrodni" ${ }^{120}$. Czynnikom brytyjskim mogło to być nie na rękę, świadcząc o ich postawie wobec Związu Sowieckiego.

Najbardziej prawdopodobne zabójstwo Kriwoziercewa przez służby sowieckie nie zostało dotychczas zbadane. W publikowanych wspomnieniach Pawła Sudopłatowa (1907-1996), zabójcy Jewhena Konowalca i nadzorującego zabójstwo Lwa Trockiego szefa wydziału NKWD ds. dywersji za granica, na temat Kriwoziercewa nie ma nawet słowa, a cała kwestia zbrodni katyńskiej potraktowana jest pobieżnie i skrótowo ${ }^{121}$. Pomóc mogły oczywiście polskie komunistyczne służby specjalne - jak zwraca uwagę jeden z autorów, już

118 J. Mackiewicz, Tajemnicza śmierć Iwana Kriwoziercowa...

119 Zob. F. Lewis, Kto zabił Kriwickiego?, w: W. Kriwicki, W tajnej służbie Stalina, tłum.

Z. Kunert, Warszawa 2000, s. 207 i n.

${ }^{120}$ Podobny wątek poruszają też twórcy polsko-brytyjskiego filmu sensacyjnego z $2018 \mathrm{r}$. Katyń - Ostatni świadek (The Last Witness, reżyseria Piotr Szkopiak).

${ }^{121}$ P. Sudopłatow, Wspomnienia niewygodnego świadka, okrojone wydanie wspomnień w języku rosyjskim, Warszawa 1999, s. 258-259. 
w tamtym czasie poważnie infiltrujące polską emigrację ${ }^{122}$ - jednak kluczową rolę odegrali w zabójstwie prawdopodobnie właśnie Sowieci.

We współczesnej Rosji nazwisko Kriwoziercewa pozostaje praktycznie nieznane. Dopiero ostatnio w telewizyjnym wywiadzie Aleksandr Gurianow, siedzący obok Nikity Pietrowa, przewodniczący Polskiej Komisji Stowarzyszenia „Memoriał”, przypomniał, że Kriwoziercew pierwszy, jak także inni, ujawnił niemieckim władzom okupacyjnym fakt pogrzebania zwłok jeńców z Kozielska w lesie katyńskim. Gurianow argumentował, by tego typu działań nie klasyfikować jako kolaboracji z faszystami ze strony Rosjanina ${ }^{123}$.

Za zabójstwem przemawia także sposób śmierci Kriwoziercewa, który nie tylko zmarł w sposób niezauważony, ale którego śmierć nie została następnie upubliczniona. Może to świadczyć o udziale służb brytyjskich, choć hipoteza taka jest znacznie mniej przekonująca. Kriwoziercew mógł być niewygodny jako rozgłaszający wiadomości o zbrodni, której po ujawnieniu w czasie wojny Brytyjczycy w żadnym razie nie upubliczniali wobec swej biernej postawy wobec propagandy ZSRR, oskarżającej o zbrodnię hitlerowskie Niemcy.

Dziwną kwestią jest jednak brak materiałów dotyczących Kriwoziercewa w archiwach brytyjskich. Podjęta przeze mnie kwerenda w National Archives w Londynie nie przyniosła żadnych rezultatów. Nie występuje w nich nikt o podobnych nazwiskach (Kriwoziercewa w różnych wersjach nazwiska czy też Łobody), włączając w to przebywajacych podobno po wojnie na Wyspach zbiegłych wraz z nim członków jego rodziny i przy okazaniu listu Savory'ego, stanowiacego przecież interpelację parlamentarzysty do ministra spraw wewnętrznych. Nie ma też wzmianki na temat Kriwoziercewa w archiwaliach dotyczących dipisów, w tym przesiedlanych z Włoch do Wielkiej Brytanii. Wszystko to robi wrażenie nieujawnienia materiałów, których istnienie jest prawdopodobne.

Podobnie rzecz ma się z orzeczeniami śmierci, podejmowanymi na Wyspach zawsze przez koronera. Jak ubolewał w 1951 r. Goetel, orzeczenie takie nie jest dotychczas znane. Próbując poszukiwań na dwóch szczeblach administracji na ten temat, otrzymałem w efekcie list elektroniczny, w którym koroner hrabstwa z dużą dozą chęci pomocy odesłał mnie znów na szczebel lokalny, informując, że trudno oczekiwać innych wiadomości, jeśli orzeczenie stanowiło, że zmarły popełnił samobójstwo przez powieszenie. W jego archiwach - twierdził koroner w liście do mnie - nic się jednak nie zachowało ${ }^{124}$.

${ }^{122}$ Th. Urban, op. cit., s. 424.

${ }^{123}$ Wypowiedź Aleksandra Gurianowa, Iwan Kriwoziercew, pierwyj skazawszij faszistam prawdu o Katyni, zastużiwajet wiecznuju pamiat' potomkow, fragment audycji Katyń i Smoleńsk w Radiu Swoboda, 10 IV 2015 r., https://www.youtube.com/watch?v=9jme3YvVRos (dostęp: 31 VII 2020), cytującego niektóre tezy artykułu Mackiewicza. Obok siedzący Nikita Pietrow (w wypowiedzi wspomniany także Parfion Kisielow).

${ }^{124}$ Tony Williams, Senior Coroner Somerset, List elektroniczny do autora w sprawie braku orzeczenia o śmierci Kriwoziercewa alias Mikhail Loboda, z dnia 11 VII 2019 r. (w zbiorach autora). 
Pozytywnie należy jednak ocenić wspomniany sensacyjny film fabularny, gdzie Kriwoziercew pozostał jednym z głównych bohaterów ${ }^{125}$. Film ten jest fikcją: główny bohater, dziennikarz, nigdy nie istniał, podobnie jak inne, polskie i brytyjskie, osoby dramatu. Niewiadoma jest także scena śmierci Kriwoziercewa, przed która mówiący po rosyjsku sprawcy proponuja mu podpisanie oświadczenia, że zbrodni dokonali Niemcy, na co ten się nie godzi. Odtwarzający rolę Kriwoziercewa Robert Więckiewicz nie jest podobny do oryginalnego bohatera ${ }^{126}$. W archiwach Instytutu Sikorskiego zachowało się jednak zdjęcie rosyjskiego chłopa, nota bene w eleganckim czarnym płaszczu przepasanym widocznym białym sznurkiem, obok tytułu rozdziału książki „Zbrodnia katyńska w świetle dokumentów: Żyjący świadek z roku 1940. Obywatel sowiecki, Rosjanin”, dotyczącego właśnie zeznań Kriwoziercewa ${ }^{127}$. Przedstawiony na zdjęciu chłop jest z kolei wysoce podobny do aktora odtwarzającego rolę Kriwoziercewa, co mogło stanowić inspirację dla twórców filmu. Przypomina on jednak postać Iwana Kriwoziercewa, jego determinację w odkryciu zbrodni i śmierć przy braku zgody na podpisanie fałszywego oświadczenia o niemieckim autorstwie zbrodni oraz niegodna $\mathrm{w}$ sprawie postawę władz brytyjskich, za co na pewno należą się słowa uznania reżyserowi i autorom filmu.

Abstrahując od fikcji, ocena pobudek postępowania Kriwoziercewa, decydującego się wystapić w roli świadka ujawnienia popełnienia fragmentu zbrodni, nie nastręcza natomiast większych trudności. Jest jednak istotna do zestawienia motywów składania zeznań, także na podstawie niepublikowanych dotychczas częściowo ocen tej postaci dokonanych przez Goetla.

Spośród dostępnych danych dawny prezes polskiego PEN Clubu miał na temat Kriwoziercewa pogląd najbardziej pozytywny. W niepublikowanej relacji pisał co prawda, że Kriwoziercew zrobił na nim

wrażenie człowieka dziwnego nieco i trudnego, ale opętanego myślą wyjawienia prześladującej go sprawy katyńskiej, w której chciałby wziąć odwet być może i za swojego ojca, o którym wyraża się zawsze z największą czcią i który był niezawodnie

${ }^{125}$ Do filmu odnosi się także niemiecki dziennikarz Thomas Urban, w wydanej ostatnio ciekawej pracy (op. cit.). Autor słusznie zauważa inne nieścisłości w filmie: nieistniejący artykuł dziennikarza na temat zbrodni katyńskiej, opublikowany po jego śmierci (który Urban nazywa raportem; s. 425), czy też mylne stwierdzenie autorów filmu, że Kriwoziercew to naoczny świadek mordu (jak była już mowa, twierdził tak Mackiewicz, a ostatnio także Eugenia Maresch). Nieprawdą jest jednak stwierdzenie Urbana, że występujący w głównej roli reporter (jak słusznie pisze autor, „postać fikcyjna, wymyślona przez scenarzystów”) „został potem zamordowany przez brytyjskie służby”. Th. Urban, op. cit.

${ }^{126}$ Prawdopodobne zdjęcie Kriwoziercewa zob. np.: ibidem, s. 424 (ilustracja). Por. także ilustracje zawarte w Niemieckim urzędowym materiale..., z którego zdjęcie zaczerpnął również Urban.

${ }^{127}$ AIPMS, kol. 13/3, fotografia, k. nlb. Obok znajduje się także przemycone w bucie zdjęcie z obozu w Kozielsku (widać na nim jednak tylko niewielki staw i zarośla). 
wielkim autorytetem moralnym dla niego. Kriwoziercew jest człowiekiem prostym, jeśli chodzi o sferę i wykształcenie, ale skomplikowanym, jako umysłowość. W przekonaniu swoim jest przeznaczony do spełnienia jakiegoś wielkiego zadania, którego sprawa katyńska jest bodajże pierwszym tylko etapem. Stąd można mieć wrażenie, że jest [człowiekiem] niezupełnie normalnym. Zeznania jego sa jednak dokładne, obserwacje bystre, wnioski nieraz daleko idące. Ponieważ w sprawie katyńskiej okazuje fantastyczny upór i nastaje ciagle, aby wystapić przed publicznym sądem w jakichkolwiek warunkach, przedstawia w sprawie katyńskiej świadka nieocenionej wartości ${ }^{128}$.

Po jego śmierci Goetel stwierdzał też, że „kto miał możność zetknać się z tym człowiekiem i z jego furią wewnętrzna, z jaką chciał dojść prawdy o Katyniu, rozumiał jak ważny był los i życie Kriwoziercowa"129. Mackiewicz pisał z kolei:

Widziałem go w Katyniu. Ale w pamięci pozostał mi takim, jakim oglądałem go we Włoszech, w Anconie: siedział na pryczy drewnianej, zgarbiony niepokojem o własny los, rozczochrując włosy nerwowym drapaniem. Gdy przypominam sobie dziś tamtą sylwetkę i zestawiam los Kriwoziercowa, autentycznego świadka największej zbrodni popełnionej w czasie ubiegłej wojny [...] - odczuwam to jak temat wielkiej, ludzkiej powieści, z jej nigdy nie zbadanymi wyrokami. W danym wypadku powieści o wielkiej niesprawiedliwości świata i ponurym epilogu ${ }^{130}$.

Mackiewicz dodawał jednak, że Kriwoziercew, będący „chłopem rosyjskim o bardzo średniej inteligencji”, miał rozbudzone ambicje w związku ze sprawa katyńska „, że ważność świadectw jakie nosił w swej pamięci rozbudzała w nim nadzieje i że świadectwa te chciał może sprzedać nie wiadomo jak drogo!"131

Goetel konkludował, że w Ankonie obaj Rosjanie w dużym podnieceniu spodziewali się zemsty ze strony bolszewików. Jak zauważał, musiał też zadać sobie „wiele trudu, aby przetrzymywać wybuchy sarkazmu i gniewu,

${ }^{128}$ Ibidem, Relacja F. Goetla z rozmów z Kriwoziercewem, 20 XII 1946; podobnie: ibidem, P. Jankowski, Uwagi do protokołu Iwana Kriwoziercewa, spisanego w Niemczech w dniu 31 maja 1945 roku, 21.11.1951 r., k. 37d. W prowadzonym dochodzeniu po śmierci Kriwoziercewa (przytaczając relację mjr. Gruberta) stwierdzano, że „Kriwoziercew jest średnio inteligentny, pisze z dużą trudnościa, jednak jest dość sprytny, orientuje się w znaczeniu sprawy. Poza tym doskonale wie, co go czeka po drugiej stronie. Wobec tego - konkluduje 14.3.1946 r. p. Grubert - Kriwoziercew o ile nie jest pod bezpośrednią opieką kogoś zainteresowanego, to w każdym razie nie przebywa na terytorium pod kontrola sowiecka". Ibidem, P. Jankowski, Uwagi do protokołu Iwana Kriwoziercewa, spisanego w Niemczech w dniu 31 maja 1945 roku, 21.11.1951 r., k. 37d.

129 F. Goetel, Zachód i Katyń, „Wiadomości” R. VI, (Londyn) 8 VII 1951, nr 27 (275), przedruk m.in. w: Katyń. Wybór publicystyki..., s. 107-109.

${ }^{130}$ Mackiewicz zestawia Kriwoziercewa z fałszywie zeznajacym przed Komisja Maddena świadkiem w białym kapturze, obserwujaccym rzekomo z drzewa, w dodatku noca, egzekucje w Kozich Górach.

131 J. Mackiewicz, Tajemnicza śmierć Iwana Kriwoziercowa... 
którymi raz po raz zaskakiwał Kriwoziercew, niezmiernie zapamiętały w poczuciu krzywdy, która dotknęła jego rodzinę, jak i tej drugiej, publicznej, która zdaniem jego obchodzić musiała cały świat. Nie mógł zrozumieć”. Dalej Goetel pisał:

dlaczego my, Polacy, nie wytaczamy sprawy Katynia przed forum świata, nie wołamy na alarm, nie umieliśmy przedstawić jej na procesie norymberskim. Na niektórych ludzi, którzy się z nim stykali, robił wrażenie człowieka nienormalnego. I był nim niezawodnie, jak nienormalny jest dziś człowiek, który spraw moralnych chce dochodzić na prostej drodze. Powątpiewań w prawdziwość swej postawy nie obudzał we mnie żadnych. Przywrócił mi także i zachwianą już wiarę w poczucie humanitaryzmu, zawarte w duszy rosyjskiego ludu. Wychowany już w Rosji bolszewickiej, należał do młodego pokolenia. Relacja jego świadczyła, że nie był wyjątkiem w swoim otoczeniu. Tu, w Ankonie, na obcym mu zupełnie gruncie, budził współczucie, graniczące ze zdumieniem, tak jak budziły je kiedyś w Warszawie tabory wsi rosyjskich ciagnących na Zachód w nadziei, że odnajdą tam zagubioną prawdę o życiu i treść życia. Pił. Pijany zjawiał się nieraz u mnie, miotając wyzwiska i domagając się, aby go niezwłocznie zetknać z sądami angielskimi czy amerykańskimi. Przypominałem mu wówczas doświadczenia poczynione z prokuratorem amerykańskim. Odchodził zgnębiony. Niósł w sobie rozpacz, trawiąca go nieustannie. Spotkawszy go wówczas we Włoszech nie wiedziałem jeszcze, że kiedyś, gdy zginie już na terenie Anglii w tajemniczych okolicznościach, będę musiał przyjąć i jego katyńskie rzecznictwo ${ }^{132}$.

Rzecznictwo takie, jak ujął to polski pisarz, doprowadziło do ujawnienia po upadku komunizmu wielu aspektów zbrodni katyńskiej, w tym prawie wszystkich innych miejsc mordu. Duża w tym zasługa polskich badaczy na emigracji i w kraju, dzięki którym przez ponad pół wieku zbrodnia katyńska nie została zapomniana. To zasługa również rosyjskich chłopów - na ile mogli, przekazywali wiedzę o niektórych okolicznościach zbrodni. Takich jak przede wszystkim Kriwoziercew.

Chociaż szczątkowe, wspomnienia Iwana Kriwoziercewa są interesujace jako przykład autentycznego świadectwa chłopa, mocno pokrzywdzonego przez zbrodniczą „władzę sowiecka”, który świadectwo to złożył po przedostaniu się na Zachód. Inni nie byli skłonni do zwierzeń, słusznie upatrując szansy na przeżycie w tym, by jak najszybciej o nich zapomniano. Relacja Kriwoziercewa jest oczywiście bardzo ważna z powodu drobnych stosunkowo, ale przez lata pierwszoplanowych szczegółów zbrodni katyńskiej. Szczegóły takie sa istotne także współcześnie. Poznamy je do końca po otwarciu archiwów rosyjskich, a w mniejszym stopniu także brytyjskich. Być może dowiemy się wtedy także nieznanych do dziśs szczegółów śmierci Iwana Kriwoziercewa.

${ }^{132}$ F. Goetel, Czasy wojny..., s. 273-274, wyd. 2, Gdańsk 2000, s. 148. 


\section{Streszczenie}

Celem artykułu jest przedstawienie nieznanych aspektów biografii rosyjskiego chłopa Iwana Kriwoziercewa (1915-1947), będącego najważniejszym świadkiem zbrodni katyńskiej od zakończenia II wojny światowej do publikacji rosyjskich zeznań oprawców na początku lat dziewięćdziesiątych. Opierając się w znacznej mierze na rosyjskich i emigracyjnych polskich, dostępnych w Londynie, materiałach archiwalnych, często po raz pierwszy w literaturze przedmiotu, artykuł przedstawia szczegóły represji i śmierci ojca świadka, dostępne obecnie informacje na temat jego rodziny, ucieczki z miejsca zamieszkania, kompletu zeznań składanych polskim władzom i pisarzom oraz śledztwa podjętego po niewyjaśnionej do dziś śmierci Kriwoziercewa. Przedmiotem artykułu są także prawnicza analiza i weryfikacja zeznań złożonych przez Kriwoziercewa, ocena pobudek postępowania świadka i rekonstrukcja charakteru postaci, także w związku z sensacyjnym filmem fabularnym zrealizowanym ostatnio na temat śmierci Kriwoziercewa. Paradoksalnie materiałów na temat postaci Iwana Kriwoziercewa nie ma zbyt wiele, a dostępne powielają ustalenia sprzed wielu lat. Co okazało się zaskoczeniem, ustalenia zawarte w artykule pozwoliły także na skorygowanie kilku innych twierdzeń, związanych z osobą świadka, głównie w oparciu o materiały archiwalne.

\section{Ivan Krivozertsev as a Wittness to Some of the Circumstances of the Katyn Massacre}

The article aims to present unknown aspects of the biography of the Russian peasant Ivan Krivozertsev (1915-1947), who was the most important witness of the Katyn massacre from the end of World War II to the publication of Russian testimonies of the perpetrators in the early 1990s. Based mainly on Russian and Polish emigrational London archival materials, often used for the first time in the literature on the subject, the article presents details of the repression and death of the witness's father, information currently accessible on his family, escape from his place of residence, complete testimony given to Polish authorities and writers and the investigation carried out after the still-unexplained death of Ivan Krivozertsev. The subject of the article is also the legal analysis and verification of testimonies made by Ivan Krivozertsev, the assessment of the reasons for his conduct and the reconstruction of the personal character. This is also made in relation to the sensational film made recently about the death of Ivan Krivozertsev, which, despite recalling a specific person, is a feature film. Paradoxically, there is not much material on the figure of Ivan Krivozertsev, and the available ones duplicate findings from many years ago. Surprisingly, the article's conclusions also made it possible to correct several other statements related to the witness, mainly based on archival materials.

\section{Bibliografia}

Figes O., Szepty. Życie w stalinowskiej Rosji, tłum. W. Jeżewski, Warszawa 2008.

Goetel F., Czasy wojny, wyd. 1, Londyn 1955, wyd. 2, Gdańsk 2000.

Katyń. Wybór publicystyki 1943-1988 i „Lista Katyńska”, Londyn 1988.

Lebiediewa N.S., Komisja specjalna $i$ jej przewodniczacy Burdenko, w: Zbrodnia katyńska między prawdq i ktamstwem, red. M. Tarczyński, Warszawa 2008 (,Zeszyty Katyńskie”, nr 23).

Lewis F., Kto zabit Kriwickiego?, w: W. Kriwicki, W tajnej stużbie Stalina, tłum. Z. Kunert, Warszawa 2000.

Mackiewicz J., Katyń. Zbrodnia bez sqdu i kary, zebrał i oprac. J. Trznadel, t. I, Warszawa 1997. 
Mackiewicz J., Tajemnicza śmierć Iwana Kriwoziercowa, głównego świadka zbrodni katyńskiej, „Wiadomości” R. VII, (Londyn) 20 IV 1952, nr 15-16 (315-316), http://retropress.pl/ wiadomosci/tajemnicza-smierc-iwana-kriwoziercowa-glownego-swiadka-zbrodni-katynskiej/ (dostęp: 27 VII 2020).

Maresch E., Katyń 1940, tłum. z ang. M. Urbański, Warszawa 2014.

Niemiecki urzędowy materiat $w$ sprawie masowego mordu w Katyniu, red. nauk. A. Bosiacki, tłum. P. Bentkowski, Warszawa 2020.

Pietrow N., Poczet katów katyńskich, tłum. J. Prus-Wojciechowska, Warszawa 2015.

Platajs J., Zbrodnia katyńska. Zeznania świadków przed polskimi sqdami wojskowymi 1943-1946, Gdańsk 2016.

Savory D.L., O rzezi w Katyniu, „Wiadomości”, (Londyn) 10 IV 1949, nr 15.

Swianiewicz S., W cieniu Katynia, Paryż 1989.

Trznadel J., Rosyjscy świadkowie Katynia (1943-1946-1991), w: Zbrodnia katyńska. Droga do prawdy, red. M. Tarczyński, Warszawa 1992 („Zeszyty Katyńskie”, nr 2).

Urban Th., Katyń. Zbrodnia i walka propagandowa wielkich mocarstw, tłum. E. Ziegler-Brodnicka, Warszawa 2019.

Weber C., Krieg der Täter. Die Massenerschießungen von Katyń, Hamburg 2015.

Wolsza T., Jak Sowieci mścili się na lekarzach katyńskich, https://nowahistoria.interia.pl (dostęp: 6 III 2020).

Wolsza T., Katyń 1940. Świadkowie i świadectwa (PDF udostępniony dzięki uprzejmości Autora).

Wolsza T., „To co widziałem przekracza swa groza najśmielsze fantazje”. Wojenne i powojenne losy Polaków wizytujacych Katyń w 1943 roku, Warszawa 2015.

Zachenter A., Oni wciaż sa i robia swoje, „Dziennik Polski”, 14 IX 2009, https://dziennikpolski24.pl/oni-wciaz-sa-i-robia-swoje/ar/2646822 (dostęp: 17 VII 2020).

Adam Bosiacki - prof. dr hab., profesor nauk prawnych, prawnik i historyk prawa. Profesor zwyczajny na Wydziale Prawa i Administracji Uniwersytetu Warszawskiego, kierownik Katedry Historii Doktryn Polityczno-Prawnych, adwokat. W działalności naukowej koncentruje się m.in. na zagadnieniach historii Rosji i ZSRR, systemach totalitarnych, dziejach prawa Europy Środkowo-Wschodniej, historii administracji, w tym samorządu terytorialnego i korporacyjnego, dziejach myśli prawnej (zwłaszcza nowożytnej), dziejach nauki. E-mail: abosiacki@wpia.uw.edu.pl.

Adam Bosiacki - prof. dr hab., professor of legal sciences, lawyer and historian of law. Full professor at the Faculty of Law and Administration of the University of Warsaw, head of the Chair of the History of Political and Legal Doctrines, solicitor. In his scientific activity he focuses, among others, on the issues of the history of Russia and the USSR, totalitarian systems, the history of law of Central and Eastern Europe, and of administration, including local and corporate self-government, the history of legal thought (especially modern), the history of science. E-mail: abosiacki@wpia.uw.edu.pl. 